\title{
Raising the Pole for Min in the Temple of Isis at Shanhūr ${ }^{*}$
}

\author{
Hierzu Tafel XIX-XXIV
}

The Roman Period temple of Shanhūr (Taf. XIX, fig. 1), located c. $20 \mathrm{~km}$ north of Luxor on the east bank of the Nile, has been under investigation by the KU Leuven from 1989 until $2001^{1}$. While originally the focus of the project was mainly epigraphic, archaeological excavation was also carried out in and around the temple with increasing intensity. In 2000-2001 excavations focused on the areas surrounding the northern and western exterior walls, where a large mound of soil was heaped up against the temple. The excavations revealed evidence of Late Roman and early Islamic occupation, as well as several column bases that form the remains of a colonnade once surrounding the temple (Taf. XX, fig. 3). The first register of scenes on the western exterior wall, which had mostly been covered up by the mound of soil until then, also emerged from the ground. Since these scenes had been protected for centuries, unexposed to the same forces of erosion as the rest of the temple, they showed for the first time the fine craftsmanship with which these reliefs were once executed ${ }^{2}$. In 2010 a final epigraphic

* This article is based on a paper presented at the fourth Ptolemaic Summer School in Oostduinkerke (Belgium) in September 2011. As always, the discussion was stimulating, and we thank the participants for their useful observations. We are in particular grateful to René Preys, Troy Sagrillo, and Harco Willems for comments on a draft and most valuable suggestions.

Shanhûr I; Quaegebeur and Traunecker 1994; Quaegebeur 1995; Quaegebeur 1997; Traunecker and Willems 1998. For a recent overview see De Meyer and Minas-Nerpel 2012.

The present state of the walls of Shanhūr is quite weathered, which, in combination with the inferior quality of the limestone, has led to overall badly preserved reliefs; see Quaegebeur and Traunecker 1994, 191-192, and fig. 9a-c for drawings of the exte- campaign was undertaken in a joint project by Swansea University and KU Leuven to complete the recording for the second epigraphic volume of the Shanhūr temple, containing the scenes and inscriptions on the exterior walls ${ }^{3}$. The eastern and western exterior walls (Taf. XIX, fig. 2) were decorated under emperor Claudius (41-54 $\mathrm{CE}$ ) in three registers of twelve scenes, resulting in a total of thirty-six scenes on each wall. One of the best preserved scenes that emerged on the first register of the western exterior wall (Shanhûr II, forthcoming, scene 123) shows Claudius executing the ritual of raising the pole for Min (Tafel XXI, figs. 4-5). This scene is remarkable for several reasons, but most importantly it is the only example of all known poleraising scenes mentioning a date for this ritual.

The ritual of raising the pole $\left(s^{c} h^{c} k^{3} s h n . t\right)^{4}$ of the cult chapel of Min is well-known from the

rior walls with indications of the layout of the scenes. Fig. 9c also shows the mound of sand heaped up against the western exterior wall until 2000.

We thank the Gerda Henkel Foundation (Düsseldorf, Germany) for generously funding the final phase of this project. The mission (August-October 2010) was jointly directed by Martina Minas-Nerpel (Swansea) and Harco Willems (Leuven). Further team members were Marleen De Meyer (Leuven), Peter Dils (Leipzig), René Preys (Leuven), and Troy Sagrillo (Swansea).

This ritual is sometimes referred to as the poleclimbing ritual ('Klettern für Min'), but the climbing seems secondary to the actual goal of the ritual, which is to raise the pole. A count of the scenes, of which the state of preservation and publication allows determination, shows that in the scenes preceding the GraecoRoman Period, climbers only occur in seven out of fourteen scenes (app. 1, 2, 7, 12, 14, 16, 19). However, in the Graeco-Roman Period, all nine published scenes show climbers and not once are the poles depicted without them (app. 23, 25, 26, 27, 28, 29, 30, 31, 32). 
Old Kingdom onwards. Munro 1983, Decker and Herb 1994, and Feder 1998, 2013 collected altogether twenty-eight attestations of this ritual, dating from the reign of Pepi II to the Roman period ${ }^{5}$. Besides the Graeco-Roman Period examples, the evidence dates predominantly to the New Kingdom and comes mainly from the temples at Luxor and Karnak. Two Persian Period examples are known from the reign of Darius I in the temple of Hibis. The Graeco-Roman scenes nearly all come from Edfu and Dendera except for one scene, which dates to the reign of Philipp Arrhidaeus and is located in his sanctuary at Karnak. We can add four additional scenes to Munro's, Decker and Herb's, and Feder's collections, bringing the total to thirty-two ${ }^{6}$ : one in the temple of Amenhotep III at Soleb (app. 13), one in the Ptolemaic mammisi at Edfu (app. 28), one in Athribis dating to the reign of Claudius (app. 31), and the one at Shanhūr also dating to the reign of Claudius (app. 32). So far, the temples of Shanhür and Athribis are the most recent examples of this kind of scene. The appendix on pp. 160-163 provides a chronological and up-to-date overview of all the pole-raising scenes known to us.

For the evidence and respective bibliographies see Munro 1983, 51-53 (Appendix 2); Decker and Herb 1994, vol. I, 123-131 (Dokumentation B 1-24: Das Errichten des Stangengerüsts für das shn.tGebäude) and vol. II, pl. 54-61; and Feder 1998, 31 54. Their studies are based on Gauthier's 1931 and Lacau's 1953 publications and insights. For the evidence of the Graeco-Roman period see Beinlich 2008, vol. 1, 241-243. Beinlich also mentions the axially corresponding scenes, which are - according to Beinlich - mostly not interconnected, except for the offering scenes of lettuce (see discussion below) and eye-paint. Recently, translations of the Graeco-Roman scenes from Edfu and Dendera have been published by Feder 2013. We are grateful to Frank Feder and Joachim Quack, the editor of the volume, for sending us the manuscript in November 2012 before publication.

We are much obliged to Christian Leitz and Daniela Mendel-Leitz for drawing our attention to the scene in Athribis (app. 31) and for sharing with us the unpublished material in September 2011. We also sincerely thank Ghislaine Widmer for drawing our attention to the scene in Soleb (app. 13) and Cédric Larcher for sending us his article before its publication in $\mathrm{RdE}$ 62 (Larche 2011).
The scene numbers of this appendix are used throughout this article for referencing (referred to as 'app.').

\section{Scene 123 on the western exterior wall at Shanhūr (app. 32, Taf. XXI, figs. 4-5)}

Claudius faces Min while in his left hand he carries a ceremonial $m k s$-staff ${ }^{7}$ with a lotus motif on the middle of the shaft, and a second staff that is damaged, presumably a $h \underline{d-m a c e}{ }^{8}$. With his outstretched right arm he once either held a shm-sceptre or a hts- or $n h b$.t-sceptre ${ }^{10}$ as can be seen in other examples of this type of scene. The Roman pharaoh wears a nms and a complex hmhm-crown, the 'Roaring One'. This triple form of the $3 t f$ is flanked by ostrich feathers and set on ram horns. Each of the three rushes is embellished on its face by a sun disc and crowned by a solarised falcon ${ }^{11}$. The $h \mathrm{mhm}$ crown is related to the $3 t f$ and might be associated with renewal ${ }^{12}$, which would suit the cultic connotations of this scene, as is discussed below, but here it especially seems to relate to the more violent epithets of Min that are apparent in this scene.

Min is depicted in his typical anthropomorphic, mummiform, and ithyphallic manner, standing upright and holding a flail in his upraised right hand. He wears the double feather crown with a solar disc, and a now damaged pectoral adorned his chest. Behind the god, his cult chapel and an entry gate including a pole

For a discussion of the staff, see Jéquier 1921, 173-176; Fischer 1978, 24-25.

${ }^{8}$ For parallels, see app. 4, 7, 11, 14, 17, 19, 23, 24, $25,29,30$.

For parallels, see app. 11, 13, 14, 15, 19, 24, 25

Parker 1979, 55, n. 4; Kaplony 1986, 1376, n. 53. For parallels, see app. 4, 7, 9, 10, 12, 21, 23, 30.

${ }^{11}$ This crown also shows elements of the Lower Egyptian crown, namely the curled wires and the top part of the vertical back of the red crown. According to Vassilika 1989, 90 and 304 (type HMBN 2), this combination may denote a double crown with added emphasis on Lower Egypt. For the hmhm-crown see also Abubakr 1937, 63-65; Collier 1996, 52, 68; Goebs 2001, 323-324.

${ }^{12}$ Collier 1996, 52, 68. 
crowned by $i 3 w . t$-horns, are depicted. The ritual that is being enacted shows eight men ${ }^{13}$, each wearing two feathers ${ }^{14}$ on their head and clad in what appears to be an animal skin, climbing four poles that support a central one, the latter being crowned by a crescent moon.

Royal name ${ }^{15}$

[1] nsw.t-bj.tj nb-t3.wj (tjbrjs klwtjs)

[2] $s^{3}-r^{c} n b-h^{c} \cdot w(k j s r s[n t j]$ hwj grmnjks wtgrtr)

[1] King of Upper and Lower Egypt, Lord of the Two Lands, (Tiberios Klaudios)

[2] Son of Ra, Lord of the Crowns, (Kaisaros Sebastos ${ }^{16}$ Germanikos Autokrator)

The title of the scene is written in front of Claudius

[3] [s] $]^{c} h^{c} k 3$ shn.t $n$ it $=$ fn ibd 2 šmw sw $19^{17}$

${ }^{13}$ The number of climbers in any given pole-raising scene can vary considerably, from four (app. 14, 16) up to ten (app. 23, 25). In app. 30, there are eight climbers plus eight men who support the poles with ropes. The supporters with ropes are only rarely depicted, but they do already occur in the oldest scene dating to the reign of Pepi II (app. 1) where they are ten in number. The same number of supporters appears in app. 7, which in general seems heavily modeled after app. 1. In two cases (app. 23, 25) the climbers clinging to the middle poles are hanging upside down.

${ }^{14}$ The feathers suggest that these men are foreigners (Feder 1998, 43). According to Goedicke 2002, 250, the feathers indicate that these men are soldiers. In his study on ethnicity Espinel 2006, 171-172, does not offer any clear solution either about the ethnic origin of the pole-climbers. In a Dendera pole-raising scene (app. $30)$ the climbers are clearly called $w r . w$ nn n.w his.wt 'these great ones of the foreign lands' (see Feder 2013, 61, 64-65).

${ }^{15}$ For a collection of Claudius' cartouches and other names see Gauthier 1917, 47-62, von Beckerath 1999, 254-255, and Hallof 2010, 69-85 (only the cartouche names). Among eighty-four different throne names in Hallof's compilation, Tiberius Klaudios is listed in twenty-four variant writings, limited to el-Qal'a and with one example at Shanhūr (CL/T.51-75). For Kaisaros Sebastos Germanikos Autokrator the closest parallels outside Shanhūr are again from el-Qal'a (CL/E.22, CL/E.34 and CL/E.49). This seems to demonstrate that there was a local tradition in the Coptite area, reflected in two of the Roman period temples. The different writings of Claudius' prenomen and nomen at Shanhūr will be discussed in more detail in Shanhûr II.

${ }^{16}$ Sebastos is written in the common Egyptian translation as (ntj) hwj. See von Beckerath 1999, 250.
[3] Raising the $k$ j-pole of the tent/cult chapel for his father in month 2 of the $\check{s} m w$-season (Payni), day 19.

\section{Royal Randzeile}

[4] $\operatorname{ssp} . n[=i] n=i \ldots{ }^{18}[\ldots] g s . w-p r[\ldots] \ldots{ }^{19}[\ldots]$ his.wt ${ }^{20}[\ldots]$

[4] I have accepted for me ... [...] temple [...] ... $[\ldots]$ foreign lands ... [...]

Min's name and titles

[5] [dd $m d w$ in $m n w\left(\right.$ or $\left.m n w-r^{\circ}\right) \ldots n b$ ?] gbtjw $w^{21} n b$ ipw $h r . j h t j . w=f^{22}$

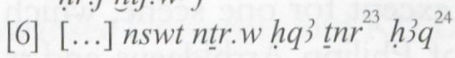

The number of days is not entirely clear. The number 10 is clearly legible, as are the five strokes at the end of the line. In between them, three strokes are visible that are not centered in the column, but offset to the right. This leaves a space for a fourth stroke on the left that is now, however, no longer preserved. Due to the placement of the three strokes, day 19 seems the most likely number and is to be preferred over day 18 .

${ }^{18}$ There are still two hieroglyphs partly recognizable, perhaps $>$ and $m$ ?

${ }^{19}$ Again, there are some hieroglyphs recognizable, but we are unable to make sense of the context: a m and $a<$ are clearly readable, with a flat sign above them. The next two squares are entirely destroyed, which is then followed by the back of a bovine animal and $\mathrm{a} \bullet$ below it.

${ }^{20}$ Only several strokes remain of the hieroglyphs, and only a mm is recognizable.

${ }^{21}$ Either mnw gbtjw.j, 'Min, the Coptite' (Edfou II 85, 2; Shanhûr I, scenes 12 and 34) or mnw nb gbtjw, 'Min, Lord of Coptos', one of Min's main epithets.

${ }^{22}$ Typical epithet of Min, see Saleh 1969, 110-120 (in particular 119); Wb III 348; LGG V 374a-b.

Wb V 382; LGG V 529c.

${ }^{24}$ For $h 3 q(w)$ see LGG V 26b-27c. This word can be used as an epithet on its own ('Beutemacher') or can be combined with an object. As the beginning of column 7 is destroyed, it is not clear whether an object followed, or whether an entirely new epithet began at the top of the column. If $h i q(w)$ is taken as an epithet on its own, especially LGG V 27b, Funktion C is interesting: as a protective god he crushes the enemies of Osiris. In general, the word $h i q$ is frequently used in relation to Osiris. Perhaps this indicates that in this scene Min is to be interpreted as a form of Osiris, with the king, as his son Horus, offering $n i t=f$ "to his father" (column 3) as the son of the local god. See also Traunecker (1992), 360-361, who established that at Coptos the funerary rituals for Min/Osiris were carried out by the living form of Min/Horus for his father. In that same manner, Claudius/Horus fulfills rites here for his father Min/Osiris. 


\section{[7] [...] hmhm nšn.tj ${ }^{25} n b n r w^{26}$}

[8] [... $]^{27}$ hrp $($ hrp? -$) q n w^{28}$ snd $=f m$ t3.wj

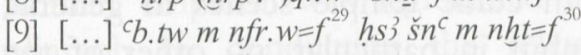

[5] [Words spoken by Min (or Min-Ra)... Lord of?] Coptos, Lord of Panopolis (Akhmim), who is on top of his stairway,

[6] [...] King of the gods, strong sovereign, who captures

[7] $[\ldots]$ who roars when he rages, lord of fear,

[8] [...] the one who brings into control the warhorses, whose fear is in the Two Lands,

[9] [...] about whose beauty one boasts, who inflicts terror/scares away with his strength.

Min's words

[10] $d j=i \quad n=k$ h 3 s.wt $r(\text { sj.wt })^{31} \ldots[\ldots]$

[10] I give you the (southern) foreign lands ... [...]

${ }^{25}$ Written nšn.wt, but should be read as a stative $n s ̌ n . t j$. See Kurth 2008, 725, \140.

${ }^{26}$ Wilson 1997, 526: $n$ b nrw: Min as a bull.

${ }^{27}$ At the beginning of this column, the word nrw from the previous column should be continued, presumably with determatives, for example the head of a vulture and a $t$-sign or a cross above the arm.

${ }^{28}$ LGG V 950c: hrp.t qnw 'die das Streitroß leitet': epithet of $R^{c} \cdot t-t 3 . w j$, not of Min. However, Wb III 328, 19: hrp nfr.w: Hipparches; nfr.w for 'horses' and Wb III 329, 3: hrp-qnw 'Streitroß'. hrp is written twice, once phonetically for hrrp 'leader' and once as only the hrpsign to form the combined word hrp-qnw.

${ }^{29}$ LGG II $82 \mathrm{~b}-83 \mathrm{a}:{ }^{c} b \quad m \quad n f r . w=f$ 'Der sich seiner Schönheit/Vollkommenheit rühmt' and 'ch.tw $m$ nfr.w $=f$ 'Dessen Schönheit man rühmt'. See Wb II 260, 7: cb m $n f r . w=f$ "der sich seiner Schönheit rühmt" als Bezeichnung des ityphallischen Min; $n f r . w$ can also be used to refer to the phallus (see Wb II 261, 8; Wilson 1997 , 515). For parallels in combination with the next epithet, see the following footnote.

${ }^{30}$ Wb III 161, 9; LGG V 480c. Epithet of Min: For a parallel of ${ }^{c} b . t w m n f r . w=f h s^{3} \check{s}^{c} m \quad n h t=f$ see Edfou II 56, 8 (a pole-raising scene, app. 25); see Feder 2013, 55) and Edfou II 85, 2 (offering black and green eye paint: w'd $m s d m . t$ ). For $n h t$ as 'phallus' see Wils on 1997, 515, 543; see also Gauthier 1931, 138-139.

The niw. $t$ sign could be a determinative for his.wt; see Gauthier 1927, IV, 155, s.v. 'khasou'. One would like to read his.wt rsj.wt, but no traces are left of the word following his.wt except for a prominent $r$. The $r$, however, should rather be written underneath the $s w$ plant and not above it. See Edfou I 376, 2 and Edfou XII, pl. 329 (pole-raising before Min and Isis, app. 23; see Feder 2013, 52-53) for the Gegengabe of Isis, concluding with his.wt rsj.wt, written in a similar fashion with a $s w$ right next to the $r$ above the three plural strokes. However, the niw.t sign is usually not combined with an additional ideogram stroke, so one wonders

\section{Divine Randzeile}

[11] Lost.

Several iconographic elements in this scene at Shanhūr are unusual. The crescent moon on top of the central pole (Taf. XXII, fig. 6.4) is unique (see Taf. XXII, fig. 6 for the different styles of depicting the tops). It does not resemble the forked ending (Taf. XXII, fig. 6.1) that occurs in many of the earlier pole-raising scenes, which is more narrow and similar in shape to the bottom part of a $w 3 s$-sceptre ${ }^{32}$. This forked ending is not found in any of the Graeco-Roman examples as far as can be ascertained. In fact, in the GraecoRoman scenes the pole is topped most often by a miniature version of the shn.t-cult shrine with the $33 w t$-sceptre in front (Taf. XXII, fig. 6.2) ${ }^{33}$. One could suggest that the top of the Shanhūr pole represents a badly executed version of the horns of the $i 3 w . t$-symbol, but since this symbol is depicted in large size and with correctly formed horns behind Min, this seems unlikely. While a crescent moon is not found in any of the other pole-raising scenes, this is certainly what it most closely resembles, and it would tie in with Min's lunar connection ${ }^{34}$. Only two other scenes have another entirely different top on the pole, namely app. 23 and 25. These scenes from Edfu resemble each other in many regards ${ }^{35}$ and both date from the reign of Ptolemy IV. The climbers seem to latch onto poles that are tied to the central pole with a noose (Taf. XXII, fig. 6.3). The element that tops the pole itself is

whether to read $h r$ instead. However, it should rather be the preposition $h r$ instead of $h r$, see for example von Pfeil-Autenrieht 2009, 73, 78. The presentation of the foreign lands by Min is a common element in the pole-climbing scenes, see for instance Edfou II 56,7; Dendera XII/1 159,13; Dendera IX/1 82,7 (see Feder 2013, 55, 60, 63).

App. 2, 3, 9, 10, 12, 17, 18, 19.

33 App. 27, 29, 30.

${ }^{34}$ Bonnet 1952, 464-465. See also below the discussion of the lunar connections of the Min festival in Thebes. Perhaps not insignificantly, Min is described in one of the other Ptolemaic pole-raising scenes as $s w ~ m j$. 'he is like the moon' (Edfou I 375, 17; see also Feder 2013, 53).

${ }^{35}$ They are also the only two scenes, in which poleclimbers are depicted upside down; see n. 13 above. 
not clear, but it could perhaps be the loop of the knot in the rope.

The pose of the eight pole-climbers is also unusual in the Shanhūr scene (see Taf. XXII, fig. 7 for the different styles of depicting the climbers). In fact, it seems that in this regard a chronological evolution can be discerned in the pole-raising scenes as well. While in the early scenes the climbers are depicted in a realistic manner, clinging onto the poles with their arms and legs wrapped around them (Taf. XXII, fig. 7.1) ${ }^{36}$, the Graeco-Roman scenes tend to show the men as if they are walking up against the poles (Taf. XXII, fig. 7.2), in a manner that seems hardly realistic and is reminiscent of the pose one has when climbing a ladder ${ }^{37}$. The scene from Shanhūr does not even resemble that: the men seem to hang onto the poles only by their arms, and their legs dangle freely in midair (Taf. XXII, fig. 7.3).

\section{Commentary}

\section{Date}

The most intriguing element in this scene is undoubtedly the date mentioned in the title: "raising the $k$ 3-pole of the tent/cult chapel for his father in month 2 of the $\check{s} m w$-season (Payni),

\footnotetext{
${ }^{36}$ App. 1, 2, 7, 14, 16, 19, 23, 25.

App. 26, 27, 28, 29, 30. This is also true for a climbing scene en miniature, which is used, according to the rebus principle, with a phonetic value $s$ (the acrophonic value of $\left.s^{c} h^{c} k^{3} s h n . t\right)$ in the temple of Khnum at Esna. Interestingly, the central pole is lacking altogether (see Taf. XXII, fig. 7.4 of this article). The hieroglyph forms part of a writing of the name of Osiris in an Osiris litany, located on a column of the Hypostyle Hall and dated to the reign of Trajan (98-117 CE): Esna no. 208, 27 (73). For the entire litany see Esna III, 3839 (no. 208). For a translation see Esna VIII, 42-43, and for a short comment on the climbing scene see Esna VIII, 120 (35) and Feder 1998, 38. According to Valeurs I 13, no. 223, it is the only attestation for the usage of this sign, but it seems to be a variant writing of the climbing sign with a central pole with the phonetic value shnt (A 234: See also Kurth 2007, 128, no. 7c: "Phonogramm ś", and p. 149, n. 68. For the use of Min's cult chapel in Esna according to the same principles, see below n. 82 .
}

day 19". Specific dates like these are very rarely mentioned in cultic temple scenes in general, and at Shanhūr in particular, no other of the preserved scenes refer to a specific date for a certain ritual. The very fact that a date is mentioned suggests that this ritual actually took place, perhaps annually, and that the depiction of it is not merely a generic decorative element.

Before discussing the date of the ritual, a brief word must be said about its significance. Pole-raising is not a sportive competition, as assumed early last century by Wilhelm Max Müller ${ }^{38}$, but a ritual dedicated to raising the pole (called $k 3$ "the bull") of the cult chapel of Min, which is often depicted behind him, such as here in the Shanhūr scene. Feder presumes that the raising of the pole was originally a temple festival, not a popular folk festival as is the case with the great Min festival at Thebes ${ }^{39}$. At the same time, however, he thinks it possible that poleraising could have become a part of the great Min festival.

By enacting the ritual of raising and climbing the pole, the king ensures the continuation of Min's cult and demonstrates his power over the subdued people in the south and the desert regions, with which Min is associated. In repeating Min's deeds, he takes over his qualities and characteristics $^{40}$. The epithets used in this scene clearly resonate the intimidation that accompanies this act: Min is the 'lord of fear' who 'inflicts terror' or 'scares away with his strength" ${ }^{41}$. In addition, Claudius' complex hm hm-crown closely relates to one of Min's epithets, 'who roars when he rages', visualizing that the king takes over the divine characteristics. The ritual is thus part of the royal cult, which guarantees the Roman em-

${ }^{38}$ Müller 1906, 34-36.

39 Feder 1998, 44. Already Gauthier 1931, 201202, had realized certain parallels between the great Min festival and the ritual of pole-raising.

40 The importance of the Min-festival in relation to the continued royal legitimization during the New Kingdom is expressed in Roth 2006, 220-226.

${ }^{41}$ For the interpretation of Min not only as a fertility god, but also as a protector against evil and enemies by means of phallic intimidation and arm lifting, see $\mathrm{Og}$ don 1985-1986, 29-41, and Wilkins on 1991-1992, $109-115$. 
peror's ability to rule as pharaoh. In theory, the Roman emperor was legitimised as Egyptian pharaoh by conducting the relevant rituals, which is reflected in ritual scenes like the poleraising for Min. Although a non-Egyptian, he was in theory the high priest who approached the divine power in order to sustain maat and thus the well-being of the world ${ }^{42}$.

According to the principle of do ut des, Min rewards the pharaoh for conducting this ritual by giving him the foreign or desert lands, presumably also relating to the Eastern desert region, as Min expresses in his words to the king ${ }^{43}$.

The date on which this re-enactment is to take place at Shanhūr, day 19 of the second month of $\check{s} m w$ (Payni), is a local date that seems to fit in well with other Min festivals in the region $^{44}$. Several feasts for Min are known from festival calendars all through Egypt ${ }^{45}$, but the largest and best known feast is certainly the pr.t $m n w r h t j . w$, Min's procession to the stairway. This festival is dated to day 11 of the first month of $\check{s} m w$ (Pachons) in the festival calendar of Medinet Habu: "Day of the Procession to the Stairway, when the New Moon is on the mor-

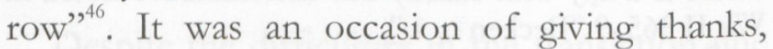

${ }^{42}$ In everyday rituals the priests fulfilled assigned duties, officially in the name of pharaoh, but the king was the essential element of the iconographic system. However, outside the pictorial context he seems to have been conceptually dispensable (Baines 1997, 230231). Hölbl 2000, 18, 117, hence concludes that the Roman emperor should be seen as a 'cultic pharaoh', who had lost his historical significance. For the Roman emperor as Egyptian pharaoh see also Minas-Nerpel 2012, 374-378.

${ }^{43}$ See also Feder 1998, 39, 43.

${ }^{44}$ For the specific meaning of day 19 in the lunar calendar, see Spalinger 1994, 52-54. We are grateful to Joachim Quack for drawing our attention to this publication. Spalinger mainly concentrates on the feast of Thoth and its special relation to day 19 of the first month of the civil calendar, but our festival is celebrated in a different month. However, Spalinger alludes to the validity of day 19 in each single month. Grimm, 1994, 408, for example, mentions festivals for Haroeris and Panebtaui for the $19^{\text {th }}$ of Payni in Kom Ombo.

${ }^{45}$ For an overview, see Gauthier 1931, 1-13; Bleeker $1956,67-68$.

${ }^{46}$ KRI V 182. See also Gundlach 1982, 142. An ostracon from Deir el-Medina mentions p3 šm.t mnw $r$ $h t j . w$ on day 11 of the first month of $\check{s} m w$, which there- when nature was reconciled after its goods were harvested. This festival also emphasised pharaoh's fertility and thus his power in ruling Egypt. The canonical Min festival goes back to the Old Kingdom $^{47}$, but the ritual of raising the pole and erecting the chapel for Min is not part of it, or at least it is not depicted as being part of it. However, on the pylon of Ramesses II at Luxor temple, pole-raising and the canonical Min festival are closely connected ${ }^{48}$. The scene in Soleb (app. 13) dating to the reign of Amenhotep III now clearly shows the raising of the pole depicted among the other festivities of the pr.t mnw festival, which confirms that this ritual already formed part of this great festival even before the version of the Ramesside Period ${ }^{49}$. Moreover, the Min festival at Soleb is depicted in the context of the Sed-festival, suggesting that the presence of Min was essential for renewing the king's authority on the throne during the Sed-festival.

At Coptos, where Min was the main deity, three feasts were celebrated in his honour during the Ptolemaic Period, one of which took place on the second day of the second month of $\check{s} m w^{50}$. At Shanhūr, which is geographically located between Thebes and Coptos, the ritual erection of Min's shrine thus occurs about one month after the Theban feast (assuming that it was still celebrated there at the same time during the Graeco-Roman Period) and less than two weeks after the Coptite feast.

\section{Context}

The topics expressed in the pole-raising scene all relate to the foreign regions, and the aspect of subduing them through Min's impressive appearance, whose characteristics are conferred upon the king. There is a clear sense of dominance and the infliction of fear, but no reference

fore must refer to the same festival as pr.t mnw $r$ htj.w (Gasse 1986).
Gauthier 1931, 15-35.
${ }^{48}$ Feder 1998, 35, 42. Gundlach 1982, 143.
${ }^{49}$ Larcher 2011, 205-209.
${ }^{50}$ Gauthier 1931, 2. 
to Min as a fertility god. Instead, the aspect of fertility is expressed in the axially corresponding scene, the eleventh scene of the lowest register on the eastern exterior wall (Shanhûr II, forthcoming, scene 161; Taf. XXII, fig. 8 and Taf. XXIII, fig. 9). This scene depicts Claudius, whose cartouches are destroyed, offering lettuce to Min and Horus the Child (Harpokrates). Lettuce (lactuca sativa) was generally associated with Min, possibly because of the resemblance that its milky sap bears to human semen ${ }^{51}$. The king again wears the hmhm-crown. Behind Min the shn.t cult chapel and the pole crowned by $33 w . t$ horns are placed, identical to the corresponding pole-raising scene on the western exterior wall. The space that is reserved on the west wall for the pole-climbers, is filled on the east wall with a depiction of Horus the Child. Although the inscriptions of the lettuce scene are fairly damaged, the surviving texts can be read as follows:

\section{Scene 161 on the eastern exterior wall at Shanhūr (figs. 8-9)}

\section{[1]-[2] cartouches lost (except for their outlines)}

King's words:

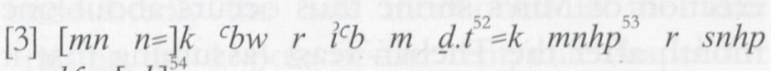
$h^{c} \cdot w[=k]^{54}$

${ }^{51}$ Germer 1980, 85-87. She makes it clear, however, that one cannot assume from this resemblance that lettuce was used as an aphrodisiac. For Min's connection with lettuce and his significance as a fertility divinity see also Bonnet 1952, 462-463.

${ }^{52}$ Either to be translated as 'phallus', even without a determinative (Wb V 506, 13), or as 'body' (Wb V 503, $10-13 ; 504,5)$.

${ }^{53}$ Wb II 82, 18. Wilson 1997, 431: related to $n h p$ "to procreate".

For snhp see Wb IV 168; Wilson 1997, 866867 ; causative of $n h p$ "to procreate". Note the wordplay in ${ }^{b} b r i^{C} b$ and mnhp $r$ snhp. The sign above the phallus seems to be a flesh sign, not a $t$. The area around it is heavily damaged but there could have been three flesh signs, forming the word $h^{c} . w$ with the phallus as a determinative, as the object of $\operatorname{snh} p$ (for $\operatorname{snh} p h^{c} . w=f$ see Edfou II 144, 9).
[4] [3h $3 \hat{h}]^{55} m$ sp3.t $t=k d j=i n t r j{ }^{56}=k m \ldots=k \ldots{ }^{57}$ ir. $n=k$

[5] snd.tw $n$ m3 $h r=k$

[3] [Take for] you the lettuce $\left({ }^{c} b w\right)$ in order to unite it with your body (or phallus) and lettuce (mnhp) in order to make procreative [your] phallus

[4] [that is green] in your nome. I give your basin (?) in your (?) ... (something) that you have done (that was done for you?) so

[5] that one is in fear when seeing your face.

\section{Rückenschutoformel}

[6] [ $\left.{ }^{c} n h\right]$ wis $\left[n b h^{3}=\right] f m j r^{c} \underline{d} . t$

[6] [All life] and prosperity are [around] him like Ra forever.

\section{Royal Randzeile:}

[7] [...] ntr.t. .. [smw nfr] $n \operatorname{snhp} h^{c} \cdot w=k^{58}$ stj. $n=k^{59} p 3 j^{60}$ iwr $n[=k]^{61} \quad m w=k d j=f^{62} r t^{3}\left[n=k s^{3}\right] \ldots m w p[=f]^{6}$

${ }^{55}$ For 3hih $m$ sp3.t see Edfou I 82, 9 (royal Randzeile of a lettuce offering scene). The remaining $t$-sign is likely the lower part of a sign comprising a clump of papyrus on top of a bread sign (Valeurs II 416, no. 433) oft.

Word unclear. Perhaps bj3 (hmty?)-ntr for "marvellous things", but it does not fit the context very well. There is a ntrj with exactly this determinative noted in Wb II 365, 9 "Becken o. ä.".

Three hieroglyphs can be discerned in this lacuna, a jug, a $n$, and a phallus, but we are unable to determine their meaning.

${ }^{58}$ For $[\operatorname{smw} n f r] n$ snhp $h^{c} . w=k$ see Edfou I 82, 9. The phallus would have to be read as suffix $=k$, but it could also be a determinative for $h^{c} \cdot w$ only. See also Edfou II 44, 9 for $r \operatorname{snh} p h^{c} \cdot w=f$, which Germer 1980, 87, translates as "um seinen Körper zur Überschwemmung kommen zu lassen".

Compare to Edfou II 44, 12: "Take the green fresh plants so that you may throw out your semen $(w d=k m w=k)$ ". Germer 1980, 87, translates "empfange das schöne Kraut damit du deinen Samen ausstoßest". For a variant writing see Dendera XI 30, 6-8: $w d=k$ $m t w t=k$... iwr $n=k \quad m t w t=k \quad b \underline{h}=f \quad n=k$ s) "you throw out your semen and your semen impregnates for you so that it gives birth for you to a son".

${ }^{60}$ Wb I 497, 13-14 and Wilson 1997, 345 "to copulate with; to fertilize".

For the addition of $=k$ see the variant in Dendera XI 30, 7 (see note 59 above).

${ }^{62} d j=f r t 3$ seems to be a poetic way to express $b \underline{h}$ "to give birth", see variant in Dendera XI 30, 7 (see note 59 above).

${ }^{63}$ For $w p[=f]$ see Edfou II 44, 13, which continues after $b \underline{h}=f n=k s$, with $\operatorname{prj} n=f m w p=f$. See Edfou I 82, 2: $b k 3=f$ prj $s\}=k m w p=f$. Should the $\square$ and $\triangle$ in front of $m$ $w p[=f]$ at Shanhür be interpreted as prj? See also Dendera, Isis temple, 352, 16, where a similar phrase 
[7] [...] goddess ... [the beautiful plants] for making procreative your phallus when you ejaculate, begetter, your semen impregnates for you, so that it puts into the world [for you a son] ... from/out of the top of [his] head.

Horus the Child's name and titles:

[8] $\underline{d} d m d w$ in $h r$ p 3 [hrd...]

[8] Words recited by Horus the [Child ...]

Min's name and titles:

[9]- [12] $]^{64}$ lost

[13] [...] mnmn ${ }^{65}$ hm.wt

$[13][\ldots]$ who impregnates women.

Min's words:

[14] $d j=i s ̌[\ldots]^{66}$

[15] b $\left.{ }^{c} n h h \underline{h} s\right\}=k s n^{c^{67}} m[\ldots]^{68}$

[14] I give [?...]

[15] Living $\mathrm{Ba}$, may you inspire fear with [...]

\section{Divine Randreile:}

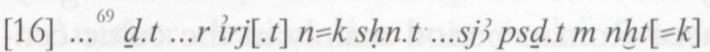

[16] ... phallus... in order to make for you the shn.ttent/chapel .... The Ennead is aware of [your] strength.

Despite the difficulties in the translation due to the fragmentary state of preservation of the texts, the theme of fertility clearly dominates the

might have stood, ending in ... $m$ - $h 3 . t$, the equivalent to $m w p=f$.

It is unclear how many columns once belonged to Min or the preceding child god, but since Min is described in five columns in the corresponding ritual scene 123 (see Taf. XXI, figs. 4 and 5) on the western exterior wall, we expect his epithets in columns 9-13.

${ }^{65} \mathrm{~Wb}$ II 81.

${ }^{66}$ The sign(s) right underneath $\breve{s}$ are too damaged to identify them, but they are followed by a phallus and an $r$.

Wb III 161 and IV 505, 12. LGG V 480b. Blackman and Fairman 1950, 70-71, no. 51. Wilson 1997,676 . The mouth following the $h s$-jar and the snake should rather be an eye, followed by the lion for $\check{s} n^{c}$.

${ }^{68}$ In the lacuna one could add $w s r=k$ or $n h t=k$, so that it should read "may you inspire fear with your strong or erect member".

${ }_{69}$ There are traces of several hieroglyphs in the top half of the Randzeile, of which we cannot make any sense without a context. scene, which is not unexpected with an offering of lettuce. While the explicit connection between the offering of lettuce and raising the pole only occurs in one other instance, namely at Dendera $^{70}$, there are other allusions to lettuce in pole-raising scenes. In two of the pole-raising parallels at Edfu and Dendera, the hts- or $n h b . t$ sceptre that the pharaoh holds in his outstretched hand strongly resembles a leaf of lettuce $^{71}$. It is quite possible that Claudius once held one such sceptre in his outstretched hand in the pole-raising scene at Shanhūr, but this section is now completely destroyed. The theme of fertility in connection with Min has been amply commented upon and needs no repeating here $^{72}$.

Thus, these complementary scenes bring out two aspects that are most important for the royal ideology, and that are also the dominant themes of the large Min festival as recorded in several New Kingdom Theban temples: fertility and victorious power.

In addition to the obvious link with the lettuce scene, the pole-raising scene appears to be tied in with another set of scenes, namely the last scenes on the first register of the eastern and western exterior walls (Shanhûr II, forthcoming, scenes 124 and 162; Taf. XXIII, fig. 10 and Taf. XXIV, Fig. 11). Scene 162 of the east wall shows Claudius presenting the temple to its main deity, in this case a female deity with a horned solar disk on her head whose name is not preserved, but who presumably is Isis, the great goddess. As has been noted by Parker ${ }^{73}$, the raising of the pole for Min is in fact an adaptation of the rite of "giving the house to its lord" (rdj.t $\operatorname{pr} n n b=f)^{74}$, the final stage in the temple

Dendera IX 54, 15-55, 3 (pl. DCCCXXIX, lettuce scene) and Dendera IX 81, 11-82, 10 (pl. DCCCXLVII; pole-raising scene; see Feder 2013, 59-61). See Beinlich 2008, vol. 1, 264: SERaT-Nr. 111140.

See app. 23 and 30.

See for example Badawy 1959/60; Germer 1980; Gundlach 1982; Goedicke 2002.

Parker 1979,55 , n. 4.

${ }^{4}$ For a collection of this scene as part of the foundation rituals in the temples of the GraecoRoman period see Beinlich 2008, 179-181, and his online-SERaT-Datenbank (www.serat.aegyptologie.uni- 
foundation ritual, but then specific for $\mathrm{Min}^{75}$. The pose of Claudius in west scene 123, holding in his left hand the ceremonial $m k s$-staff and a now damaged sceptre that was most likely a $\underline{h} \underline{d-}$ mace, and with an outstretched right arm that once also held a sceptre, also recurs in east scene 162 , building an iconographical link between both scenes. The $m k s$-staff and $h \underline{d}-$-mace are typical instruments that occur in the foundation ritual of giving the house to its lord $^{76}$.

The diagonal link along the central axis connecting west scene 123 (pole-raising, Taf. XXI, fig. 5) with east scene 162 (presentation of the temple, Taf. XXIII, fig. 10) implies that east scene 161 (lettuce, Taf. XXIII, fig. 9) should also relate to west scene 124 (Taf. XXIV, fig. 11). While hardly anything of the text of that scene is preserved, the ritual itself is clear and shows the temple surrounded by a ring that, according to parallel scenes, represents natron or gypsum $(b s n)^{77}$, which Claudius spreads around the temple in order to purify it. This scene is part of the temple foundation rituals ${ }^{78}$.

The pole-raising scene also occurs together with temple foundation rituals in other locations. At Karnak, a pole-raising scene (app. 7) appears in one of the northern chapels of

wuerzburg.de/) that comprises altogether forty-four scenes.

${ }^{75}$ The foundation rites that preceded the erection of the $k$-pole are only depicted once, on the White Chapel of Senwosret I (Lacau and Chevrier 1956, 112-118; Feder 1998, 32).

${ }^{76}$ Cooney 2000, 28.

Wb $1475,11-14$; Wils on 1997, 332. For further natron scenes see Beinlich 2008, 346-347, and his online-SERaT-Datenbank (www.serat.aegyptologie.uniwuerzburg.de/ that comprises twenty scenes, in which natron is dispersed in temples of the Graeco-Roman period. Such a ring is clearly visible, for example, in Kom Ombo I 263, where Ptolemy VIII Euergetes II purifies the temple before Haroeris and his consort Senetnefret.

${ }^{78}$ For an overview of the temple foundation rituals, including the purification with natron, see Zivie 1986. El-Adly 1981 does not include the temple's purification with natron, since it was introduced in the GraecoRoman temples only, which was beyond the scope of her book. However, on p. 94-96 she discusses the use of gypsum in the foundation rituals, which might have fulfilled the same function.
Thutmosis III, namely room XLIB that is located next to and closely related with room XLII. In the latter the foundation ritual of the temple is depicted on the south wall ${ }^{79}$. App. 15 at Karnak (Ramesses II) appears on the same wall as scenes depicting the foundation ritual ${ }^{80}$. The same is true for app. 25 (Edfu, Ptolemy IV) and app. 29 (Dendera).

Why was the pole-raising scene depicted specifically at the small temple of Shanhūr, only one of three attestations that are so far known from the Roman Period? And why was it apparently attributed significant importance, as evidenced by the mention of a specific date and the prominent position within the layout of the cultic scenes on the exterior walls?

The geographic distribution of pole-raising scenes seems significant. During the New Kingdom, it is found only in the national state temples of Karnak and Luxor, in the Late Period it only occurs in the western desert, and during the Graeco-Roman period mainly in the cultic centres of Dendera and Edfu, with a clear dominance of the latter, and once in Athribis, where the only archaeologically surviving sanctuary of $\mathrm{Min}^{81}$ is located. Surprisingly, perhaps, the scene does not occur in the other major cultic centres further to the south at Philae, Kom Ombo, or $\mathrm{Esna}^{82}$. One element that the places where poleraising scenes are found have in common, is that they are located near to well-known roads into the eastern and western desert (Edfu, Dendera, Thebes) or in the desert itself (Hibis). Shanhūr

Schwaller de Lubicz 1982, 148-150.

Nelson and Murnane 1981, pl. 258.

See Leitz et al. 2010, vol. I, pp. XLI-XLV, for a discussion about the dedication of the temple of Athribis to both Repit and Min-Re.

${ }^{82}$ Although no pole-raising scene is attested at Esna, the concept of this ritual was certainly known in that temple where a hieroglyph of pole-climbers is used as a writing for $s$ according to the rebus principle (for details, see n. 37 above). Very much in the same way, Min's entire chapel with entry gate is used in the same Osiris litany, again in the name of Osiris and again for the phonetic value $s$ (acrophonic for $s h n . t$ ): Esna no. 208, 24 (54). For the litany see Esna III, 38-39 (no. 208), and VIII, 42-43. For a short comment on the rarely used hieroglyph of the cult chapel see Esna VIII, 167 (266), and Valeurs III 516, no. 1023. 
as well lies at the crossroads with the eastern desert road. The Coptite region in general enjoyed particular interest of the Roman rulers because of exactly this strategic position that they exploited for economic reasons, since mineral resources were of great value. It is here that expeditions through the Wadi Hammamat started, mainly to the quarries at Mons Claudianus and Mons Porphyrites in the eastern desert that yielded granite and porphyry respectively. From the Coptite region, the Red Sea and Indian Ocean could be reached through wadis, an important factor for the long distance trades with India and Arabia. The region therefore acted as a gate to foreign lands. This economic interest in the Coptite region is reflected in the numerous Roman additions and decorations to already existing Egyptian temples in that area, for example in Coptos itself, as well as the building of new structures, such as at Shanhūr or elQal'a $^{83}$.

Another element that may explain why this scene is found in the small temple of Shanhür, is the temple's Coptite version of the Theban theology. At Coptos, Min was the main deity since Predynastic times. At Thebes, Min is connected or even equated to Amun, especially with the primordial creative aspect of the latter, often called Min-Amun-Re-Kamutef. In Luxor and Thebes it is therefore often Amun, not Min, for whom the cult chapel is erected ${ }^{84}$. This aspect of Amun, especially when depicted as the mummiform ithyphallic Min, emphasised the eternal and self-sustained character of the divine and royal power. The theology of the temple of Shanhūr was heavily influenced by both of these major cultic spheres, with a dominance by the Coptite one ${ }^{85}$.

${ }^{83}$ See Traunecker 1992, 3-15, for a description of the topographical settings of the area. See Pantalacci and Taunecker 1990, 1998, for a text edition of the el-Qal'a temple inscriptions.

${ }^{84}$ See Lacau 1953, 22.

${ }^{85}$ See Shanhûr I, 14-48; Willems 2007.

\section{Conclusion}

The Shanhūr pole-raising scene is, together with the Athribis scene (app. 31), so far the most recent attestation of its kind in a span of 2,300 years, from Pepi II to Claudius. Although we know that Claudius, as most Roman emperors, never visited Egypt, his rule over the land at the Nile and the desert regions was legitimized through cultic means. By decorating the exterior temple wall with this ritual, Claudius theoretically received Min's characteristics and thus his ability to rule over Egypt and to ultimately maintain maat. The axially corresponding ritual scene, in which Min and Harpokrates receive lettuce, further ensures Egypt's fertility and prosperity. The emperor ensured Egypt's prosperity by erecting Min's cult chapel, thus repeating in a mystery play (Mysterienspiel) ${ }^{86}$ on 19 Payni Min's dominance over foreign and desert regions and ensuring their tribute. This meant that not only Egypt's existence was ensured, but also that of the temple at Shanhür - an important fact that the native priests must have cared for. The importance of the pole-raising ritual at Shanhūr is moreover illustrated by the mention of a specific date, an uncommon feature in ritual scenes in general, and a unique element in all known poleraising scenes so far. Because of this element, we are able to date yet another local Min festival, which brings us a step closer to understanding the local cult topography.

\footnotetext{
${ }^{86}$ For the term 'mystery play' (Mysterienspied) in a pole-raising scene, see Dendera IX 81, 14-15 (app. 29): $i r j=s n i r . w=s n r s 3 b i b=k$, 'They enact their mystery play in order to delight your [= Min's] heart' (see Feder 2013, 59 and 64).
} 
Appendix: Pole raising scenes

\begin{tabular}{|c|c|c|c|c|c|c|c|}
\hline$\#$ & $\begin{array}{l}\text { Location } \\
\text { (in chronological } \\
\text { order) }\end{array}$ & \multicolumn{2}{|c|}{ Publication } & $\begin{array}{l}\text { Munro } \\
1983 \\
\text { App. } 2\end{array}$ & $\begin{array}{l}\text { Decker } \\
\text { and } \\
\text { Herb } \\
1994\end{array}$ & $\begin{array}{l}\text { Feder } \\
1998\end{array}$ & $\begin{array}{l}\text { Feder } \\
2013\end{array}$ \\
\hline \multirow[t]{2}{*}{1} & \multirow{2}{*}{$\begin{array}{l}\text { South Saqqara } \\
\text { Mortuary temple of } \\
\text { Pepi II, central } \\
\text { transvers corridor. }\end{array}$} & Text & $\begin{array}{l}\text { PM III/22, } 427 \text { (18), no. } 4 . \\
\text { Jéquier } 1938 \text {, pl. } 12-15 .\end{array}$ & \multirow[t]{2}{*}{1} & \multirow[t]{2}{*}{ B1 } & \multirow[t]{2}{*}{$\begin{array}{l}\text { n. } 4 \text { and } \\
\text { Abb. } 1\end{array}$} & \multirow[t]{2}{*}{ p. 48} \\
\hline & & Scene & Idem & & & & \\
\hline \multirow[t]{2}{*}{2} & \multirow{2}{*}{$\begin{array}{l}\text { Deir el-Bahari } \\
\text { Mortuary temple of } \\
\text { Mentuhotep } \\
\text { Nebhepetre }\end{array}$} & Text & (New York MMA 06.1231.33) & \multirow[t]{2}{*}{1} & \multirow[t]{2}{*}{ B2 } & & \\
\hline & & Scene & $\begin{array}{l}\text { Decker and Herb 1994, } \\
\text { pl. } 54 \text { (B2). } \\
\text { www.metmuseum.org/ } \\
\text { Collections/search-the- } \\
\text { collections/100001770 }\end{array}$ & & & & \\
\hline \multirow[t]{2}{*}{3} & \multirow[t]{2}{*}{$\begin{array}{l}\text { Karnak } \\
\text { Chapelle blanche; } \\
\text { Sesostris I. }\end{array}$} & Text & $\begin{array}{l}\mathrm{PM} \mathrm{II}^{2}, 62 . \\
\text { Lacau and Chevrier } 1956 \text {, } \\
\text { scene 8', fig. } 31,112-118 .\end{array}$ & \multirow[t]{2}{*}{2} & \multirow[t]{2}{*}{ B3 } & \multirow[t]{2}{*}{$\begin{array}{l}\text { n. } 5 \text { and } \\
\text { Abb. } 2\end{array}$} & \multirow[t]{2}{*}{$\begin{array}{l}\text { p. } 48- \\
49\end{array}$} \\
\hline & & Scene & Idem & & & & \\
\hline \multirow[t]{2}{*}{4} & \multirow[t]{2}{*}{$\begin{array}{l}\text { Karnak } \\
\text { Chapelle blanche; } \\
\text { Sesostris I. }\end{array}$} & Text & $\begin{array}{l}\text { PM II } I^{2}, 62 . \\
\text { Lacau and Chevrier 1956, } \\
\text { scene 10', fig. 31,112-118. }\end{array}$ & \multirow[t]{2}{*}{2} & \multirow[t]{2}{*}{ B4 } & \multirow[t]{2}{*}{$\begin{array}{l}\text { n. } 5 \text { and } \\
\text { Abb. } 2\end{array}$} & \multirow[t]{2}{*}{ p. $48-49$} \\
\hline & & Scene & Idem & & & & \\
\hline \multirow[t]{2}{*}{5} & \multirow{2}{*}{$\begin{array}{l}\text { Karnak } \\
\text { Alabaster bark shrine; } \\
\text { Amenhotep I.- } \\
\text { Thutmosis I. }\end{array}$} & Text & $\mathrm{PM} \mathrm{II}^{2}, 63$. & \multirow[t]{2}{*}{5} & \multirow[t]{2}{*}{ B5 } & \multirow[t]{2}{*}{ p. 33} & \multirow[t]{2}{*}{ p. 49} \\
\hline & & Scene & $\begin{array}{l}\text { Decker and Herb 1994, } \\
\text { pl. } 55 \text { (B5). }\end{array}$ & & & & \\
\hline \multirow[t]{2}{*}{6} & \multirow{2}{*}{$\begin{array}{l}\text { Karnak } \\
\text { Amun temple, room; } \\
\text { XXXIII; } \\
\text { Thutmosis III. }\end{array}$} & Text & $\mathrm{PM} \mathrm{II}^{2}, 122(419)$ & \multirow[t]{2}{*}{7} & \multirow[t]{2}{*}{ B7 } & \multirow{2}{*}{ n. 7} & p. 49 \\
\hline & & Scene & $\begin{array}{l}\text { Decker and Herb 1994, } \\
\text { pl. } 55 \text { (B7). }\end{array}$ & & & & \\
\hline 7 & $\begin{array}{l}\text { Karnak } \\
\text { Amun temple, room } \\
\text { XLI B; Thutmosis III. }\end{array}$ & Text & $\begin{array}{l}\text { PM II }{ }^{2}, 125 \text { (451), room } \\
\text { XLI B. } \\
\text { Barguet 1962, 208; } \\
\text { Schwaller De Lubicz } \\
\text { 1982a, 150. }\end{array}$ & 6 & B8 & n. 7 & p. 49 \\
\hline & & Scene & $\begin{array}{l}\text { Schwaller De Lubicz } \\
\text { 1982b, pl. 177-179. } \\
\text { Decker and Herb 1994, } \\
\text { pl. } 56 \text { (B8). }\end{array}$ & & & & \\
\hline 8 & Karnak & Text & $\mathrm{PM} \mathrm{II}^{2}, 92(266)$. & 6 & B6 & 1 & 1 \\
\hline & $\begin{array}{l}\text { Amun temple, north } \\
\text { court between } 6 \text { th } \\
\text { pylon and festival } \\
\text { temple; } \\
\text { Thutmosis III. }\end{array}$ & Scene & Unpublished & & & & \\
\hline 9 & $\begin{array}{l}\text { Karnak } \\
\text { Block from a re-used } \\
\text { bark station built into } \\
\text { the Khonsu temple; } \\
\text { Amenhotep II. }\end{array}$ & Text & $\begin{array}{l}\text { PM II }{ }^{2}, 244 \text { (Earlier blocks } \\
\text { built in). } \\
\text { Schwaller De Lubicz } \\
\text { 1982a, 173-174. } \\
\text { Schwaller De Lubicz } \\
\text { 1982b, pl. 268. }\end{array}$ & / & / & 1 & p. 49 \\
\hline & & Scene & $\begin{array}{l}\text { Schwaller De Lubicz } \\
\text { 1982b, pl. } 268 .\end{array}$ & & & & \\
\hline
\end{tabular}




\begin{tabular}{|c|c|c|c|c|c|c|c|}
\hline$\#$ & $\begin{array}{l}\text { Location } \\
\text { (in chronological } \\
\text { order) }\end{array}$ & \multicolumn{2}{|c|}{ Publication } & $\begin{array}{l}\text { Munro } \\
1983 \\
\text { App. } 2\end{array}$ & $\begin{array}{l}\text { Decker } \\
\text { and } \\
\text { Herb } \\
1994\end{array}$ & $\begin{array}{l}\text { Feder } \\
1998\end{array}$ & $\begin{array}{l}\text { Feder } \\
2013\end{array}$ \\
\hline \multirow[t]{2}{*}{10} & \multirow{2}{*}{$\begin{array}{l}\text { Luxor } \\
\text { Luxor temple, } \\
\text { north wall of the } \\
\text { 12-columned room; } \\
\text { Amenhotep III. }\end{array}$} & Text & $\begin{array}{l}\text { PM II }^{2}, 329(171) . \\
\text { Brunner } 1977 \text {, pls. } 75 \text { and } 9 .\end{array}$ & \multirow[t]{2}{*}{15} & \multirow[t]{2}{*}{ B11 } & \multirow[t]{2}{*}{$\begin{array}{l}\text { n. } 8 \text { and } \\
\text { Abb. } 3\end{array}$} & \multirow[t]{2}{*}{ p. 49} \\
\hline & & Scene & Idem & & & & \\
\hline \multirow[t]{2}{*}{11} & \multirow[t]{2}{*}{$\begin{array}{l}\text { Luxor } \\
\text { Luxor temple, west wall } \\
\text { of room VIII; } \\
\text { Amenhotep III. }\end{array}$} & Text & $\begin{array}{l}\mathrm{PM} \mathrm{II}^{2}, 322(128) \text {. } \\
\text { Gayet } 1894 \text {, pl. LIII, fig. } 100 \\
\text { (drawing shows climbers who } \\
\text { are not present in the actual } \\
\text { relief). Lac a u } 1953,18 \text {, fig. } 3 \text {. }\end{array}$ & \multirow[t]{2}{*}{14} & \multirow[t]{2}{*}{ B10 } & \multirow[t]{2}{*}{$\begin{array}{l}\text { n. } 10-11 \\
\text { and } \\
\text { Abb. } 4\end{array}$} & \multirow[t]{2}{*}{ p. 49} \\
\hline & & Scene & Idem & & & & \\
\hline \multirow[t]{2}{*}{12} & \multirow{2}{*}{$\begin{array}{l}\text { Luxor } \\
\text { Luxor temple, east wall } \\
\text { of the hypostyle hall; } \\
\text { Amenhotep III. }\end{array}$} & Text & $\begin{array}{l}\text { PM II }^{2}, 318 \text { (102). } \\
\text { Gayet } 1894 \text {, pl. X, fig. } 59 \text {. }\end{array}$ & \multirow[t]{2}{*}{13} & \multirow[t]{2}{*}{ B9 } & \multirow[t]{2}{*}{ ก. 13} & \multirow[t]{2}{*}{ p. 49} \\
\hline & & Scene & Idem & & & & \\
\hline \multirow[t]{2}{*}{13} & \multirow[t]{2}{*}{$\begin{array}{l}\text { Soleb } \\
\text { Temple of Amenhotep } \\
\text { III, first court, western } \\
\text { portico; } \\
\text { Amenhotep III. }\end{array}$} & Text & $\begin{array}{l}\text { PM VII, } 170 \text { ( } 7) \text {. } \\
\text { Schiff Giorgini et al. } 2002 \text {, } \\
304-305 \text { (R } 28 \text { A c \& d). } \\
\text { Larcher } 2011 .\end{array}$ & \multirow[t]{2}{*}{1} & \multirow[t]{2}{*}{ I } & \multirow[t]{2}{*}{ I } & \multirow[t]{2}{*}{ I } \\
\hline & & Scene & $\begin{array}{l}\text { Schiff Giorgini et al. } 1998, \\
\text { pl. } 122-123 . \\
\text { Larcher } 2011 \text {, pl. } 27 \\
\text { figs. } 1-3 \text {. }\end{array}$ & & & & \\
\hline \multirow[t]{2}{*}{14} & \multirow[t]{2}{*}{$\begin{array}{l}\text { Karnak } \\
\text { Amun temple, } \\
\text { hypostyle hall, northern } \\
\text { west wall; Seti I. }\end{array}$} & Text & $\begin{array}{l}{\mathrm{PM} \Pi^{2}, 44}(152) \text {. } \\
\text { Nels on and Murnane 1981, } \\
\text { pl. } 147 \text { (wrongly labeled as } \\
\text { pl. } 14 \text { in Feder 1998, n. 14). }\end{array}$ & \multirow[t]{2}{*}{3} & \multirow[t]{2}{*}{$\mathrm{B} 12$} & \multirow[t]{2}{*}{$\begin{array}{l}\text { n. } 14 \\
\text { and } \\
\text { Abb. } 5\end{array}$} & \multirow[t]{2}{*}{ p. 49} \\
\hline & & Scene & Idem & & & & \\
\hline \multirow[t]{2}{*}{15} & \multirow{2}{*}{$\begin{array}{l}\text { Karnak } \\
\text { Amun temple, } \\
\text { hypostyle hall, southern } \\
\text { west wall; Seti I (reused } \\
\text { by Ramesses II). }\end{array}$} & Text & $\begin{array}{l}\text { PM } \Pi^{2}, 46(157) . \\
\text { Nelson and Murnane } \\
\text { 1981, pls. } 20 \text { and } 258 .\end{array}$ & \multirow[t]{2}{*}{4} & \multirow[t]{2}{*}{$\mathrm{B} 13$} & $\begin{array}{l}\text { n. } 15 \\
\text { and } \\
\text { Abb. } 6\end{array}$ & p. 49 \\
\hline & & Scene & Idem & & & & \\
\hline 16 & $\begin{array}{l}\text { Karnak } \\
\text { Amun temple, enclo- }\end{array}$ & Text & $\begin{array}{l}\mathrm{PM} \mathrm{\Pi}^{2}, 128(469) . \\
\text { Helck } 1969 \text {, pl. } 29 \text {, p. } 33 .\end{array}$ & 9 & B14 & $\begin{array}{l}\text { n. } 16 \\
\text { and }\end{array}$ & p. 49 \\
\hline & $\begin{array}{l}\text { sure wall, south side; } \\
\text { Ramesses II. }\end{array}$ & Scene & Idem & & & $\begin{array}{l}\text { Abb. } 7 \\
\text { (oben) }\end{array}$ & \\
\hline 17 & $\begin{array}{l}\text { Karnak } \\
\text { Amun temple, enclo- }\end{array}$ & Text & $\begin{array}{l}\mathrm{PM} \mathrm{II}^{2}, 129 \text { (475). } \\
\text { Helck } 1969 \text {, pl. 94, p. } 113 .\end{array}$ & 10 & B15 & $\begin{array}{l}\text { n. } 17 \\
\text { and }\end{array}$ & p. 49 \\
\hline & $\begin{array}{l}\text { sure wall, north side; } \\
\text { Ramesses II. }\end{array}$ & Scene & Idem & & & $\begin{array}{l}\text { Abb. } 7 \\
\text { (unten) }\end{array}$ & \\
\hline 18 & $\begin{array}{l}\text { Luxor } \\
\text { Luxor temple, court of }\end{array}$ & Text & $\begin{array}{l}\mathrm{PM} \mathrm{II}^{2}, 308(28) . \\
\text { Daressy } 1893,32 .\end{array}$ & 12 & B17 & n. 18 & p. 50 \\
\hline & $\begin{array}{l}\text { Ramesses II, western } \\
\text { interior wall. }\end{array}$ & Scene & Unpublished & & & & \\
\hline 19 & $\begin{array}{l}\text { Luxor } \\
\text { Luxor temple, pylon, }\end{array}$ & Text & $\begin{array}{l}\text { PM II', } 306(17) . \\
\text { Kuentz 1971, pl. XIX. }\end{array}$ & 11 & B16 & $\begin{array}{l}\text { n. } 19 \\
\text { and }\end{array}$ & p. 50 \\
\hline & $\begin{array}{l}\text { east half, south side } \\
\text { (used to be covered by } \\
\text { mosque); Ramesses II. }\end{array}$ & Scene & Idem & & & Abb. 8 & \\
\hline
\end{tabular}




\begin{tabular}{|c|c|c|c|c|c|c|c|}
\hline$\#$ & $\begin{array}{l}\text { Location } \\
\text { (in chronological } \\
\text { order) }\end{array}$ & \multicolumn{2}{|c|}{ Publication } & $\begin{array}{l}\text { Munro } \\
1983 \\
\text { App. } 2\end{array}$ & $\begin{array}{l}\text { Decker } \\
\text { and } \\
\text { Herb } \\
1994\end{array}$ & $\begin{array}{l}\text { Feder } \\
1998\end{array}$ & $\begin{array}{l}\text { Feder } \\
2013\end{array}$ \\
\hline \multirow[t]{2}{*}{20} & \multirow{2}{*}{$\begin{array}{l}\text { Hibis (Kharga Oasis) } \\
\text { Temple of Hibis, Side- } \\
\text { room VI off the third } \\
\text { hypostyle hall, east wall; } \\
\text { Darius I. }\end{array}$} & Text & $\begin{array}{l}\text { PM VII, } 285 \text { (102). } \\
\text { Davies 1953, pl. } 22 .\end{array}$ & 16 & B18 & $\begin{array}{l}\text { n. } 34 \\
\text { and }\end{array}$ & p. 50 \\
\hline & & Scene & Idem & & & Abb. 11 & \\
\hline \multirow[t]{2}{*}{21} & \multirow{2}{*}{$\begin{array}{l}\text { Hibis (Kharga Oasis) } \\
\text { Temple of Hibis, } \\
\text { southern exterior wall; } \\
\text { Darius I. }\end{array}$} & Text & $\begin{array}{l}\text { PM VII, } 288 \text { (145)-(146). } \\
\text { Davies } 1953 \text {, pl. } 51 .\end{array}$ & 16 & B19 & $\begin{array}{l}\text { n. } 34 \\
\text { and }\end{array}$ & p. 50 \\
\hline & & Scene & Idem & & & Abb. 12 & \\
\hline \multirow[t]{2}{*}{22} & \multirow{2}{*}{$\begin{array}{l}\text { Karnak } \\
\text { Amun temple, } \\
\text { Philipp Arrhidaeus } \\
\text { sanctuary, southern } \\
\text { exterior wall (now } \\
\text { lost?). }\end{array}$} & Text & $\begin{array}{l}\mathrm{PM} \mathrm{II}^{2}, 100(291) . \\
\text { Barguet } 1962,140 .\end{array}$ & 17 & $\mathrm{~B} 20$ & n. 23 & p. 50 \\
\hline & & Scene & Unpublished & & & & \\
\hline \multirow[t]{2}{*}{23} & \multirow{2}{*}{$\begin{array}{l}\text { Edfu } \\
\text { Temple of Horus, inner } \\
\text { vestibule, west wall; } \\
\text { Ptolemy IV. }\end{array}$} & Text & $\begin{array}{l}\text { PM VI, } 142(176)-(177) \\
\text { Edfou I, } 375-376\end{array}$ & \multirow[t]{2}{*}{$19 \& 20$} & \multirow[t]{2}{*}{ B22 } & \multirow[t]{2}{*}{$\begin{array}{l}\text { n. } 24 \\
\text { and } 27\end{array}$} & \multirow{2}{*}{$\begin{array}{l}\text { p. } 50 \\
\text { Edfu A: } \\
\text { p. } 51- \\
53\end{array}$} \\
\hline & & Scene & $\begin{array}{l}\text { Edfou IX, pl. XXXIb. } \\
\text { Edfou XII, pl. CCCXXIX. }\end{array}$ & & & & \\
\hline \multirow[t]{2}{*}{24} & \multirow{2}{*}{$\begin{array}{l}\text { Edfu } \\
\text { Temple of Horus, inner } \\
\text { hypostyle hall, first } \\
\text { column; Ptolemy IV. }\end{array}$} & Text & $\begin{array}{l}\text { PM VI, } 138 \text {, columns. } \\
\text { Edfou II, } 88-89 .\end{array}$ & \multirow[t]{2}{*}{22} & \multirow[t]{2}{*}{1} & \multirow{2}{*}{$\begin{array}{l}\text { n. } 24,28, \\
\text { and } \\
\text { Abb. } 10\end{array}$} & \multirow{2}{*}{$\begin{array}{l}\text { p. } 51 \\
\text { Edfu B: } \\
\text { p. } 53-54\end{array}$} \\
\hline & & Scene & Edfou IX, pl. XLI. & & & & \\
\hline \multirow[t]{2}{*}{25} & \multirow{2}{*}{$\begin{array}{l}\text { Edfu } \\
\text { Temple of Horus, inner } \\
\text { hypostyle hall, west } \\
\text { wall; Ptolemy IV. }\end{array}$} & Text & $\begin{array}{l}\text { PM VI, 136f (110)-(114). } \\
\text { Edfou II, } 56 .\end{array}$ & \multirow[t]{2}{*}{21} & \multirow[t]{2}{*}{ B21 } & \multirow[t]{2}{*}{$\begin{array}{l}\text { n. } 24 \\
\text { and } 30\end{array}$} & \multirow{2}{*}{$\begin{array}{l}\text { p. } 52 \\
\text { Edfu C: } \\
\text { p. } 55\end{array}$} \\
\hline & & Scene & Edfou IX, pl. XLb. & & & & \\
\hline \multirow[t]{2}{*}{26} & \multirow{2}{*}{$\begin{array}{l}\text { Edfu } \\
\text { Temple of Horus, } \\
\text { forecourt, west wall; } \\
\text { Ptolemy IX. }\end{array}$} & Text & $\begin{array}{l}\text { PM VI, } 126(47)-(50) \\
\text { Edfou V, } 165-166 .\end{array}$ & \multirow[t]{2}{*}{18} & \multirow[t]{2}{*}{ B23 } & \multirow[t]{2}{*}{$\begin{array}{l}\text { n. } 25 \\
\text { and } 31\end{array}$} & \multirow{2}{*}{$\begin{array}{l}\text { p. } 51 \\
\text { Edfu D: } \\
\text { p. } 56-57\end{array}$} \\
\hline & & Scene & Edfou X, pl. CXVIII. & & & & \\
\hline \multirow[t]{2}{*}{27} & \multirow{2}{*}{$\begin{array}{l}\text { Edfu } \\
\text { Temple of Horus, } \\
\text { eastern enclosure wall; } \\
\text { Ptolemy X. }\end{array}$} & Text & $\begin{array}{l}\text { PM VI, } 167(337)-(344) \text {, top } \\
\text { register. Edfou VII, } 304 .\end{array}$ & \multirow[t]{2}{*}{1} & 1 & $\begin{array}{l}\text { n. } 26 \\
\text { and } 29\end{array}$ & $\begin{array}{l}\text { p. } 51 \\
\text { Edfu E: }\end{array}$ \\
\hline & & Scene & Edfou X, pl. CLXXII. & & & & p. $57-58$ \\
\hline 28 & $\begin{array}{l}\text { Edfu } \\
\text { Ptolemaic mammisi, }\end{array}$ & Text & $\begin{array}{l}\text { PM VI, } 175 \text { (102). } \\
\text { Edfou Mammisi, } 128 .\end{array}$ & l & 1 & I & / \\
\hline & $\begin{array}{l}\text { south intercolumnar } \\
\text { wall; Ptolemy IX. }\end{array}$ & Scene & Edfou Mammisi, pl. 30/1. & & & & \\
\hline 29 & $\begin{array}{l}\text { Dendera } \\
\text { Temple of Hathor, } \\
\text { northern wall of the } \\
\text { inner hypostyle hall; }\end{array}$ & Text & $\begin{array}{l}\text { PM VI, } 50(47) \text {, second } \\
\text { register. } \\
\text { Dend. IX } / 1,81-82 \text {. } \\
\text { Mariette, Dendarah I, pl. } 23 .\end{array}$ & 23 & B24 & n. 32 & $\begin{array}{l}\text { p. } 51 \\
\text { Den- } \\
\text { dara A: } \\
\text { p. } 58-61\end{array}$ \\
\hline & $\begin{array}{l}\text { late Ptolemaic to early } \\
\text { Roman period (empty } \\
\text { cartouches). }\end{array}$ & Scene & $\begin{array}{l}\text { Dend. IX/2, pl. } \\
\text { DCCCXLVII, DCCCLVI. }\end{array}$ & & & & \\
\hline 30 & $\begin{array}{l}\text { Dendera } \\
\text { Temple of Hathor, }\end{array}$ & Text & $\begin{array}{l}\text { PM VI, } 75 \text { (226), top register. } \\
\text { Dend. XII/1, 158-159. }\end{array}$ & l & / & / & $\begin{array}{l}\text { p. } 51 \\
\text { Den- }\end{array}$ \\
\hline & $\begin{array}{l}\text { eastern exterior wall; } \\
\text { Augustus. }\end{array}$ & Scene & Dend. XII/2, pl. 96. & & & & $\begin{array}{l}\text { dara B: } \\
\text { p. } 61-63\end{array}$ \\
\hline
\end{tabular}




\begin{tabular}{|c|c|c|c|c|c|c|c|}
\hline \# & $\begin{array}{l}\text { Location } \\
\text { (in chronological } \\
\text { order) }\end{array}$ & \multicolumn{2}{|c|}{ Publication } & $\begin{array}{l}\text { Munro } \\
1983 \\
\text { App. } 2\end{array}$ & $\begin{array}{l}\text { Decker } \\
\text { and } \\
\text { Herb } \\
1994\end{array}$ & $\begin{array}{l}\text { Feder } \\
1998\end{array}$ & $\begin{array}{l}\text { Feder } \\
2013\end{array}$ \\
\hline \multirow[t]{2}{*}{31} & \multirow{2}{*}{$\begin{array}{l}\text { Athribis/Wannina } \\
\text { Temple of Repit, } \\
\text { eastern exterior wall; } \\
\text { Claudius. }\end{array}$} & Text & $\begin{array}{l}\text { PM V, } 31 \text { (1)-(2). } \\
\text { Leitz et al. (forthcoming), } \\
\text { Athribis III, M1, } 55 \text {. }\end{array}$ & \multirow[t]{2}{*}{1} & \multirow[t]{2}{*}{ / } & \multirow[t]{2}{*}{1} & \multirow[t]{2}{*}{1} \\
\hline & & Scene & $\begin{array}{l}\text { Petrie } 1908 \text {, pl. } 23 \text { (scene } \\
\text { only partially published); } \\
\text { Leitz et al. (forthcoming), } \\
\text { Athribis III, M1, } 55 \text {. }\end{array}$ & & & & \\
\hline \multirow[t]{2}{*}{32} & \multirow[t]{2}{*}{$\begin{array}{l}\text { Shanhūr } \\
\text { Temple of Isis, western } \\
\text { exterior wall; Claudius. }\end{array}$} & Text & $\begin{array}{l}\text { PM V, } 136 . \\
\text { Shanhūr II (forthcoming), } \\
\text { scene } 123 \text {. }\end{array}$ & \multirow[t]{2}{*}{1} & \multirow[t]{2}{*}{1} & \multirow[t]{2}{*}{1} & \multirow[t]{2}{*}{1} \\
\hline & & Scene & $\begin{array}{l}\text { Idem; Minas-Nerpel, and } \\
\text { De Meyer, ZÄS } 140 \text { (2013), } \\
\text { 150-166. }\end{array}$ & & & & \\
\hline
\end{tabular}

\section{Bibliography}

Abubakr, Abd el Monem Joussef. 1937. Untersuchungen über die ägyptischen Kronen. Glückstadt, Hamburg, New York: Verlag von J.J. Augustin.

el-Adly, Sanaa Abd el-Azim. 1981. Das Gründungs- und Weihritual des ägyptischen Tempels von der frühgeschichtlichen Zeit bis zum Ende des Neuen Reiches. Tübingen: Zeeb-Druck.

Badawy, Alexandre. 1959/60. 'Min, the Cosmic Fertility God of Egypt'. MIO 7, 163-179.

Baines, John. 1997. 'Temples as Symbols, Guarantors, and Participants in Egyptian Civilization'. In Stephen Quirke (ed.), The Temple in Ancient Egypt: New Discoveries and Recent Research. London: British Museum Press, 216-241.

Barguet, Paul. 1962. Le temple d'Amon-Rê à Karnak. Essai d'exégèse. Cairo: IFAO.

von Beckerath, Jürgen. 1999. Handbuch der ägyptischen Königsnamen. $2^{\text {nd }}$ ed. MÄS 49. Mainz: Philipp von Zabern.

Beinlich, Horst. 2008. Handbuch der Szenentitel in den Tempeln der griechisch-römischen Zeit Ägyptens. Die Titel der Ritualszenen, ihre korrespondierenden Szenen und ihre Darstellungen, 2 vols., SRaT 3.1-3.2. Dettelbach: J. H. Röll.

Blackman, Aylward M., and Herbert Walter Fairman. 1950. 'The Significance of the Ceremony $h w t b h s w$ in the Temple of Horus at Edfu'. JEA $36,63-81$.

Bonnet, Hans. 1952. Reallexikon der ägyptischen Religionsgeschichte. Berlin: Walter de Gruyter.

Brunner, Hellmut. 1977. Die südlichen Räume des Tempels von Luxor. AV 18. Mainz am Rhein: Verlag Philipp von Zabern.

Brunner-Traut, Emma. 1982. 'Minfeste'. In: Wolfgang Helck and Wolfhart Westendorf (eds.), Lexikon der Ägyptologie IV. Wiesbaden: Otto Harrassowitz, 141-144.

Collier, Sandra A. 1996. The Crowns of Pharaoh: Their Development and Significance in Ancient Egyptian Kingship. Doctoral dissertation. University of California Los Angeles. UMI Dissertation Service.

Cooney, Kathlyn M. 2000. 'The Edifice of Taharqa by the Sacred Lake: Ritual Function and the Rule of the King'. JARCE 37, 15-47.

Daressy, Georges. 1893. Notice explicative des ruines du Temple de Louxor. Cairo: Service des antiquités de l'Egypte.

Davies Norman De Garis. 1953. The Temple of Hibis in El Khārgeh Oasis 3: The Decoration. PMMA 17. New York: Metropolitan Museum of Art.

Decker, Wolfgang, and Michael Herb. 1994. Bildatlas zum Sport im Alten Ägypten. Corpus der bildlichen Quellen zu Leibesübungen, Spiel, Jagd, Tanz und verwandten Themen. HdO I, 14, 1-2. Leiden, New York, Köln: E. J. Brill.

De Meyer, Marleen, and Martina Minas-Nerpel. 2012. 'Shenhur, Temple of. In Elizabeth Frood and Willemina Wendrich (eds.), UCLA Encyclopedia of Egyptology. Los Angeles: University of California, Los Angeles.

Derchain, Philippe. 1962. 'Un manuel de géographie liturgique à Edfou'. CdE 37, 31-65.

Esna III = Sauneron, Serge. 1968. Le Temple d'Esna, textes nos. 194-398. Esna III. Cairo: IFAO.

Esna VIII = Sa uneron, Serge. 1982. L'Écriture figurative dans les textes d'Esna. Esna VIII. Cairo: IFAO.

Espinel, Andrés Diego. 2006. Etnicidad y territorio en al Egipto del reino antiguo. Aula Aegyptiaca: Studia 6. Universitat Autònoma de Barcelona: Servei de Publicacions. 
Feder, Frank. 1998. 'Das Ritual $s^{c} h^{c} k 3$ shn.t als Tempelfest des Gottes Min'. In: Rolf Gundlach and Matthias Rochholz (eds.), 4. Ägyptologische Tempeltagung. Feste im Tempel. ÄAT 33.2. Wiesbaden: Harrassowitz, 31-54.

Feder, Frank. 2013. 'Das Ritual "Errichten des KaSymbols der Sehenet-Kapelle $\left(s^{c} h^{c} k j s h n . t\right)$ " in der griechisch-römischen Zeit Ägyptens'. In Joachim F. Quack (ed.), Ägyptische Rituale der griechisch-römischen Zeit, Tübingen: Mohr Siebeck, 47-65.

Fischer, Henry G. 1978. Notes on Sticks and Staves in ancient Egypt'. MMJ 13, 5-32.

Gasse, Annie. 1986. 'Une sbht d'Isis'. BIFAO 86, $171-175$.

Gauthier, Henri. 1917. Le Livre des Rois d'Égypte. Recueil des titres et protocol royaux. Noms propre des rois, reines, princes, princesses et parents de rois, suivi d'un index alphabétique. Tome V: Les empereurs Romains. MIFAO 21. Cairo: IFAO.

Gauthier, Henri. 1931. Les fêtes du dieu Min. RAPH 2. Cairo: IFAO.

Gayet, Albert. 1894. Le temple de Louxor. MIFAO 15. Cairo: IFAO.

Germer, Renate. 1980. 'Die Bedeutung des Lattichs als Pflanze des Min'. SAK 8, 85-87.

Goebs, Katja. 2001. 'Crowns'. In Donald B. Redford (ed.), The Oxford Encyclopedia of Ancient Egypt I, Oxford: Oxford University Press, $321-326$.

Goedicke, Hans. 2002. 'Min'. MDAIK 58, $247-$ 255.

Grimm, Alfred. 1994. Die altägyptischen Festkalender in den Tempeln der griechisch-römischen Epoche. ÄAT 15. Wiesbaden: Harrassowitz.

Gundlach, Rolf. 1982. 'Min'. In: Wolfgang Helck and Wolfhart Westendorf (eds.), Lexikon der Ägyptologie IV. Wiesbaden: Otto Harrassowitz, 136-140.

Hallof, Jochen. 2010. Schreibungen der Pharaonennamen in den Ritualszenen der Tempel der Griechisch-Römischen Zeit Ägyptens. Teil 2: Die römischen Kaiser. SRaT 4.2. Dettelbach: J. H. Röll.

Helck, Wolfgang. 1969. Die Ritualszenen auf der Umfassungsmauer Ramses' II. in Karnak. ÄA 18. Wiesbaden: Harrassowitz Verlag.

Helck, Wolfgang. 1980. 'Klettern für Min'. In: Wolfgang Helck and Wolfhart Westendorf (eds.), Lexikon der Ägyptologie III. Wiesbaden: Otto Harrassowitz, 454-455.

Hölbl, Günter. 2000. Altägypten im Römischen Reich. Der römische Pharao und sein Tempel I. Römische Politik und altägyptische Ideologie von Augustus bis Diocletian, Tempelbau in Oberägypten. Mainz: Philipp von Zabern.

Jéquier, Gustave. 1921. Les frises d'objets des sarcophages du moyen empire. Cairo: IFAO.
Jéquier, Gustave. 1938. Le monument funéraire de Pepi II. 2: Le temple; Fouilles à Saqqarah. Cairo: IFAO.

Kaplony, Peter. 1986. 'Zepter'. In: Wolfgang Helck and Wolfhart Westendorf (eds.), Lexikon der Ägyptologie VI. Wiesbaden: Otto Harrassowitz, 1373-1389.

KRI = Kitchen, Kenneth A. 1983. Ramesside Inscriptions. Historical and biographical V. Oxford: B. H. Blackwell Ltd.

Kuentz, Charles. 1971. La face sud du massif est du pylone de Ramses II à Louxor. Cairo: Centre de Documentation et d'Etudes sur l'Ancienne Egypte.

Kurth, Dieter. 2007. Einführung ins Ptolemäische I. Hützel: Backe Verlag.

Kurth, Dieter. 2008. Einführung ins Ptolemäische II. Hützel: Backe Verlag.

Lacau, Pierre. 1953. 'L'Érection du mât devant Amon-Min'. CdE 28, 13-22.

Lacau, Pierre and Henri Chevrier. 1956. Une chapelle de Sésostris Ier à Karnak. Cairo : IFAO.

Larcher, Cédric. 2011. 'Min et la fête-Sed: Réexamen d'une scene du temple de Soleb.' RdE 62, 205-209.

Leitz, Christian, Daniela Mendel, and Yahya elMasry. 2010. Athribis II. Der Tempel Ptolemaios XII. Die Inschriften und Reliefs der Opfersäle, des Umgangs und der Sanktuarräume. Band 1: Die Opfersäle und der Umgang. Band 2: Die Sanktuarräume. Band 3: Tafeln. Cairo: IFAO.

Leitz, Christian, Daniela Mendel, and Yahya elMasry (forthcoming). Athribis III. Der Tempel Ptolemaios XII: Die Inschriften und Reliefs der Außenwände und der westlichen Seitenkapellen, 2 volumes. Cairo: IFAO.

LGG = Leitz, Christian (ed.) 2002-2003. Lexikon der ägyptischen Götter und Götterbezeichnungen I-VIII. OLA 110-116, 129. Leuven, Paris, Dudley, MA: Uitgeverij Peeters and Departement Oosterse Studies.

Minas-Nerpel, Martina. 2012. 'Egyptian Temples of the Roman Period'. In: Christina Riggs (ed.), The Oxford Handbook of Roman Egypt. Oxford: Oxford University Press, 362-382.

Müller, Wilhelm Max. 1906. Egyptological Researches. Results of a Journey in 1904. Carnegie Institution of Washington Publication 53. Washington D.C.: Carnegie Institution.

Munro, Irmtraut. 1983. Das Zelt-Heiligtum des Min. Rekonstruktion und Deutung eines fragmentarischen Modells (Kestner-Museum 1935.200.250). MÄS 41. München and Berlin: Deutscher Kunstverlag.

Nelson, Harold Hayden, and William J. Murnane. 1981. The Great Hypostyle Hall at Karnak, Volume 1, Part 1: The Wall Reliefs; OIP 106. Chicago: The Oriental Institute of the University of Chicago, 1981. 
von Pfeil-Autenrieth, Christiane. 2009. Der Gotteslohn für die Pharaonen. Untersuchungen zu den Gegengaben in den ägyptischen Tempeln der griechisch-römischen Epoche. SRaT 6. Dettelbach: Verlag J. H. Röll.

Ogdon, Jorge. 1985-1986. 'Some Notes on the Iconography of the God Min'. BES 7, 2941.

Pantalacci, Laure, and Claude Traunecker. 1990. Le temple d'el-Qal'a I: Relevés des scènes et textes $n^{\text {os }} 1-112$. Cairo: IFAO.

Pantalacci, Laure, and Claude Traunecker. 1998. Le temple d'El-Qal'a II: Relevés des scènes et textes $n^{\text {os }} 113-294$. Cairo: IFAO.

Parker, Richard A., Jean Leclant, and Jean-Claude Goyon. 1979. The Edifice of Taharqa by the Sacred Lake of Karnak. Brown Egyptological Studies 8. Providence: Brown University Press.

Petrie, William Matthew Flinders. 1908. Athribis. BSAE 14. London: British School of Archaeology in Egypt.

Quaegebeur, Jan. 1995. 'Le temple romain de Chenhour. Remarques sur l'histoire de sa construction et sur sa décoration'. In: Dieter Kurth (ed.), 3. Ägyptologische Tempeltagung, Systeme und Programme der ägyptischen Tempeldekoration. ÄAT 33.1. Wiesbaden: Harrassowitz Verlag, 199-226.

Quaegebeur, Jan. 1997. 'Excavating the Forgotten Temple of Shenhur (Upper Egypt)'. In: Stephen G. J. Quirke (ed.), The Temple in Ancient Egypt: New Discoveries and Recent Research. London: British Museum Press, 159-167.

Quaegebeur, Jan, and Claude Traunecker, with the collaboration of Christian Casseyas, Maryvonne Chartier-Raymond, Guido Creemers, Peter Dils, and Ilse Roovers. 1994. 'Chenhour 1839-1993: État de la question et rapport des travaux de 1992 et de 1993'. CRIPEL 16, $167-$ 209.

Roth, Silke. 2006. 'Der Herrscher im Fest: zur rituellen Herrschaftslegitimation des ägyptischen Königs und ihrer Außendarstellung im Rahmen von Festen'. In: Dirk Bröckelmann and Andrea Klug (eds.), In Pharaos Staat; Festschrift für Rolf Gundlach zum 75. Geburtstag. Wiesbaden: Harrassowitz Verlag, 205-249.

Saleh, Abdel-Azis. 1969. 'The So-called "Primeval Hill" and Other Related Elevations in Ancient Egyptian Mythology'. MDAIK 25, 110-120.

Schiff Giorgini, Michela, Clément Robichon, Jean Leclant, Nathalie Beaux, and Liza Majerus. 1998. Soleb 5. Le temple: bas-reliefs et inscriptions. Cairo: IFAO.

Schiff Giorgini, Michela, Clément Robichon, Jean Leclant, and Nathalie Beaux. 2002. Soleb 3. Le temple: description. Cairo: IFAO.
Schwaller de Lubicz, Rene Adolphe. 1982a. Les temples de Karnak: contribution à l'étude de la pensée pharaonique I: Texte. Paris: Dervy-livres.

Schwaller de Lubicz, Rene Adolphe. 1982b. Les temples de Karnak: contribution à l'étude de la pensée pharaonique II: Planches photographiques. Paris: Dervy-livres.

Sethe, Kurt. 1934. 'Das alte Ritual zur Stiftung von Königstatuen bei der Einweihung eines Tempels'. ZÄS 70, 51-56.

Shanhûr I = Willems, Harco, Filip Coppens, and Marleen De Meyer. 2003. The Temple of Shanhûr I: The Sanctuary, the Wabet, and the Gates of the Central Hall and the Great Vestibule (1-98), OLA 124, Leuven: Uitgeverij Peeters.

Shanhûr II = Minas-Nerpel, Martina, and Harco Willems (eds.). In preparation. The Temple of Shanhûr II: The Hypostyle Hall, the Lateral Chapel, and the Exterior of the Augustan Temple. OLA. Leuven: Uitgeverij Peeters.

Spalinger, Antony J. (ed). 1994. Revolutions in Time. Studies in Ancient Egyptian Calendrics. VA Supplement 6. San Antonio: Van Siclen.

Traunecker, Claude. 1992. Coptos. Hommes et dieux sur le parvis de Geb. OLA 43. Leuven: Uitgeverij Peeters and Departement Oriëntalistiek.

Traunecker, Claude, and Harco Willems, with the collaboration of Maryvonne Chartier-Raymond, Filip Coppens, Peter Dils, Brigitte Gratien, Dirk Huyge, Frédéric Muller, and Ilse Roovers. 1998. 'Chenhour: Rapport des travaux de 1996 et 1997'. CRIPEL 19, 111146.

Valeurs = Daumas, François, et al. 1988-1995. Valeurs phonétiques des signes hiéroglyphiques d'époque gréco-romaine I-IV. Montpellier: Institute d'Égyptologie.

Vassilika, Eleni. 1989. Ptolemaic Philae. OLA 34. Leuven: Uitgeverij Peeters and Departement Oriëntalistiek.

$\mathrm{Wb}=$ Erman, Adolf, and Herrmann Grapow. 1926-1931. Das Wörterbuch der Ägyptischen Sprache I-V. Leipzig: J. C. Hinrichs'sche Buchhandlung.

Wessetzky, Vilmos. 1984. 'Anmerkungen über das "Klettern für Min” '. GM 75, 57-58.

Wickett, Elizabeth. 2009. 'Archaeological Memory, the Leitmotifs of Ancient Egyptian Festival Tradition and Cultural Legacy in the Festival Tradition of Luxor: The Mulid of Sidi Abu'l Hajjaj al-Uqsori and the Ancient Egyptian "Feast of Opet”'. JARCE 45, 403-426 (esp. 421-423).

Wilkinson, Richard H. 1991-1992. 'Ancient Near Eastern Raised-Arm Figures and the Iconography of the Egyptian God Min'. BES 11, 109-118.

Wilson, Penelope. 1997. A Ptolemaic Lexicon. A Lexicographical Study of the Texts in the Temple 
of Edfu. OLA 78. Leuven: Uitgeverij Peeters en Departement Oosterse Studies.

Winter, Erich. 1987. 'Weitere Beobachtungen zur "grammaire du temple" in der griechischrömischen Zeit'. In: Wolfgang Helck (ed.), Tempel und Kult. ÄA 46. Wiesbaden: Harrassowitz, 61-76.

Zivie, Christiane M. 1986. 'Tempelgründung'. In: Wolfgang Helck and Wolfhart Westendorf (eds.), Lexikon der Ägyptologie VI. Wiesbaden: Otto Harrassowitz, 385-386.

\section{Summary}

This article presents the translation and commentary of two unpublished offering scenes from the eastern and western external walls of the Roman period temple at Shanhūr. Pharaoh Claudius (41-54 CE) raises the pole for Min's cult chapel and presents lettuce to the same god in the corresponding scene. The pole-raising scene is quite exceptional for many reasons, but mainly because a specific date is mentioned for this ritual, a unique element in all known pole-raising scenes so far, which enables us to date a local Min festival. The appendix provides a chronological and up-to-date overview of all known thirty-two pole-raising scenes from the Old Kingdom to the Roman Period.

\section{Keywords}

Claudius - dating temple ritual scenes - pole-raising (pole-climbing) for Min - Shanhūr - temples of the Roman period - temple decoration 


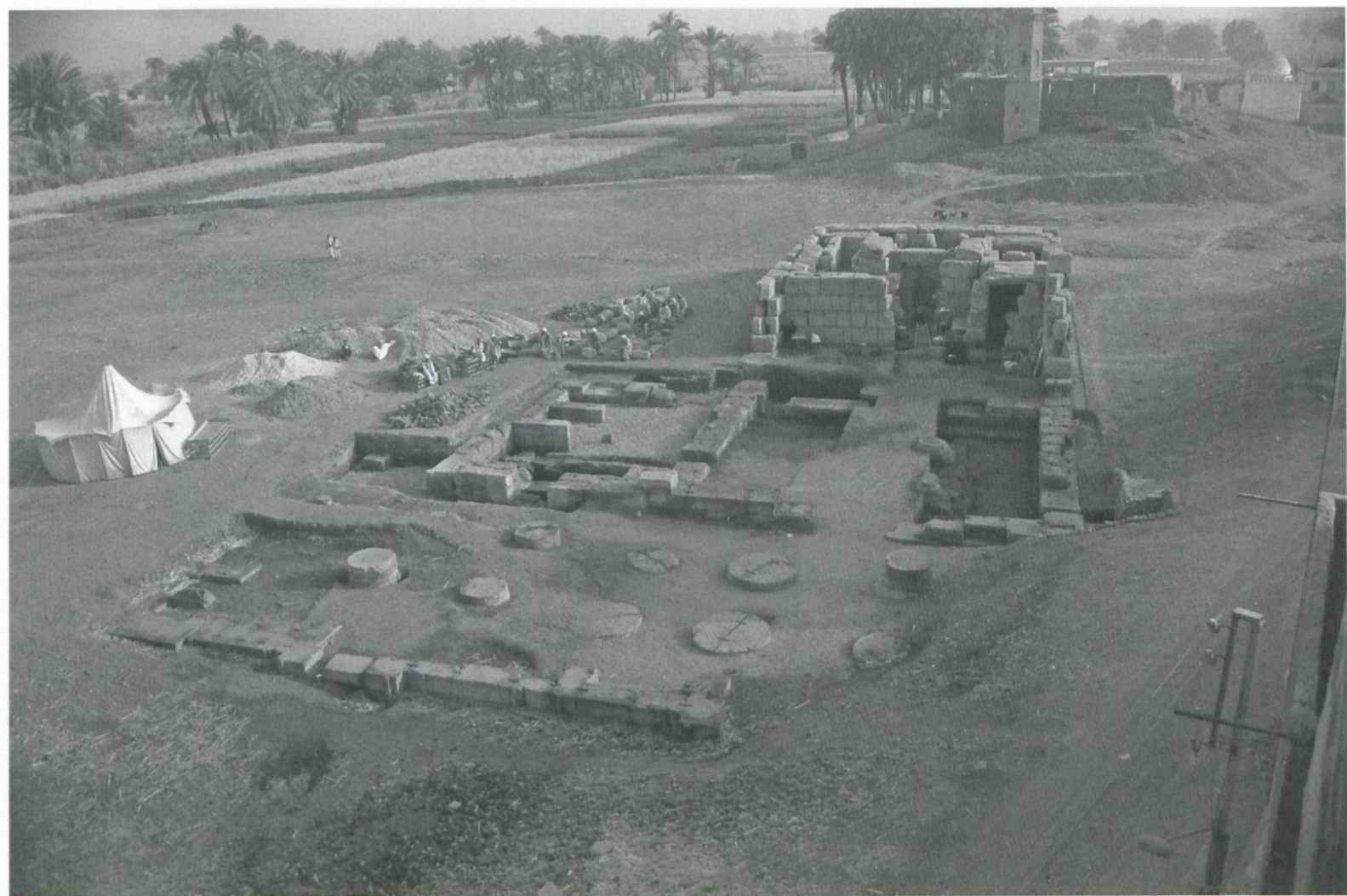

1. Shanhūr temple overview (photograph by M. De Meyer) (zu Minas-Nerpel und De Meyer, Raising the Pole for Min)

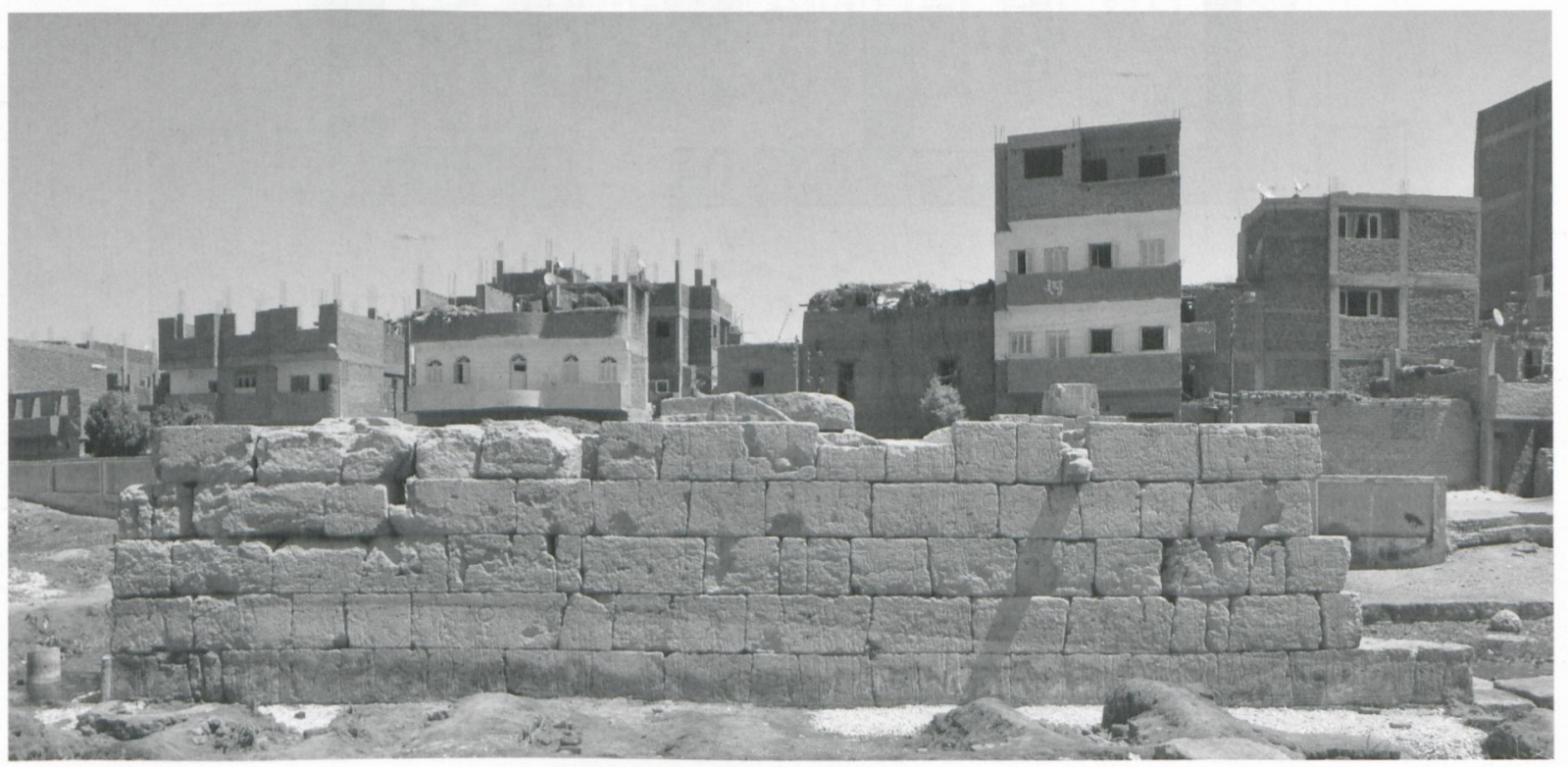

2. Western exterior wall of Shanhūr temple (photograph by M. De Meyer) (zu Minas-Nerpel und De Meyer, Raising the Pole for Min). 
$\therefore$ (ब) (-) (-) (-)

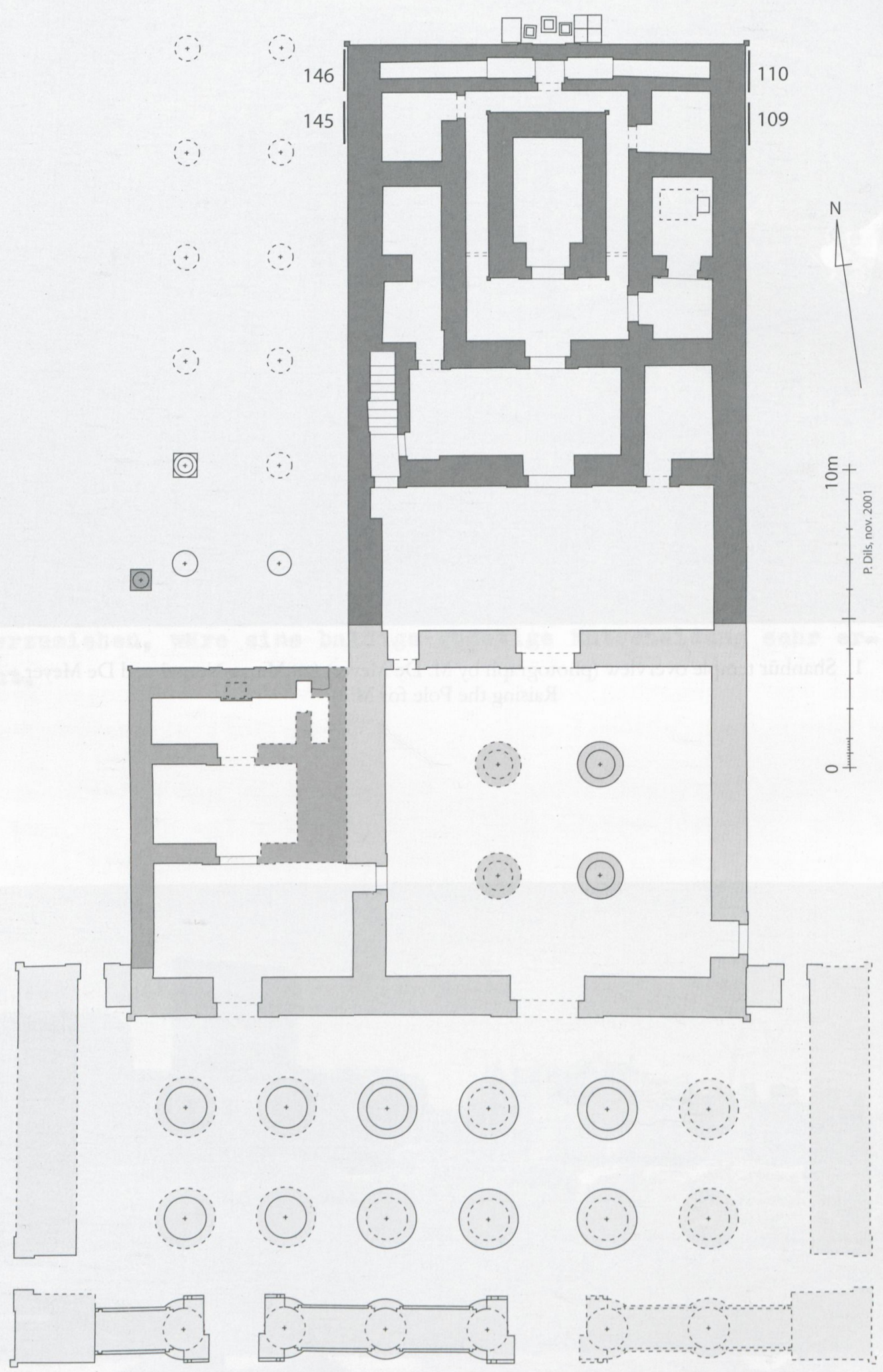

3. Plan of the Shanhūr temple with scenes 123 and 161 (pole-climbing and lettuce) and scenes 124 and 162 (temple foundation) indicated on the eastern and western exterior wall (adapted from Shanhûr I, pl. 3) (zu Minas-Nerpel und De Meyer, Raising the Pole for Min). 


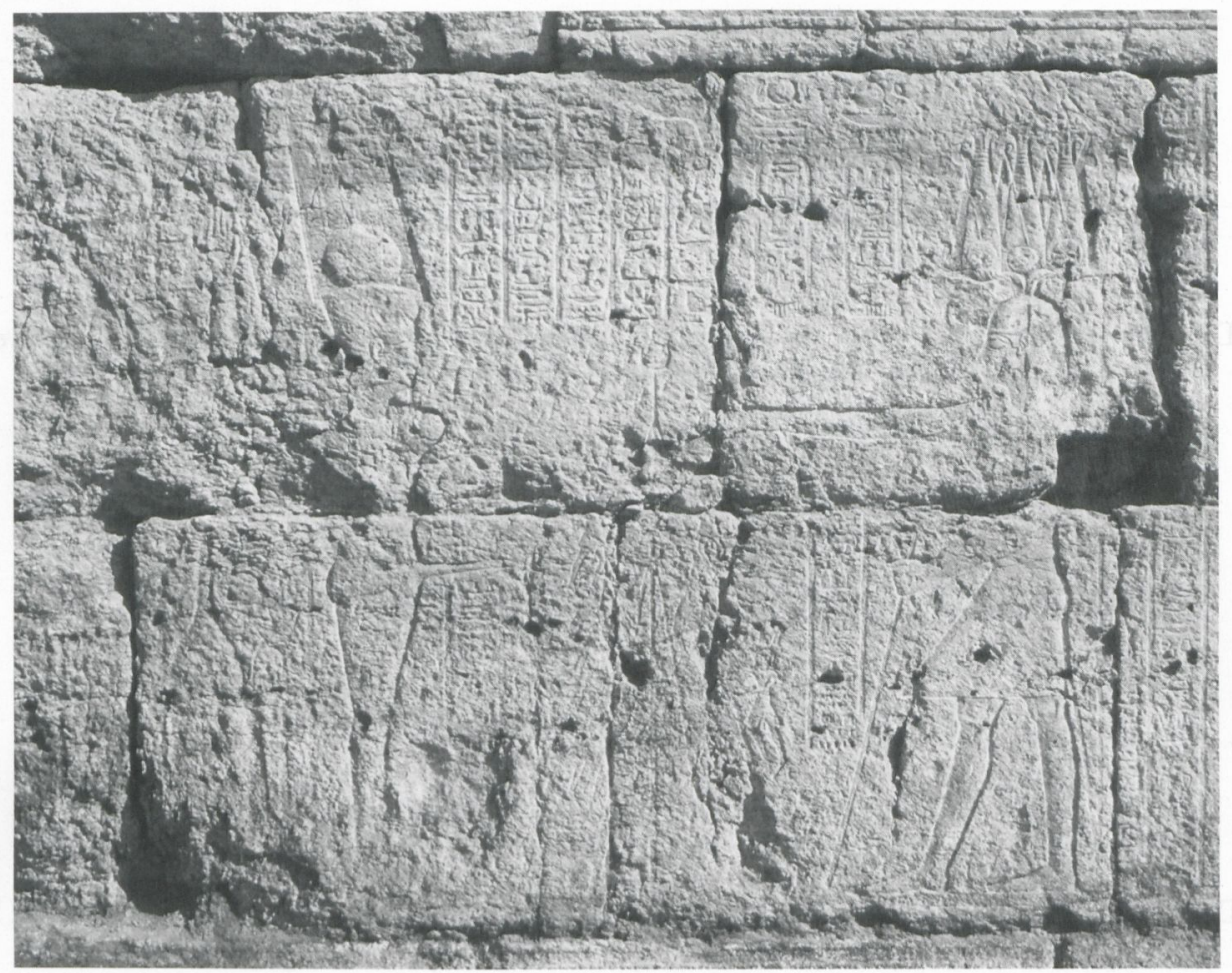

4. Photograph of Shanhūr scene 123 on the Western exterior wall (photograph by M. De Meyer) (zu Minas-Nerpel und De Meyer, Raising the Pole for Min).

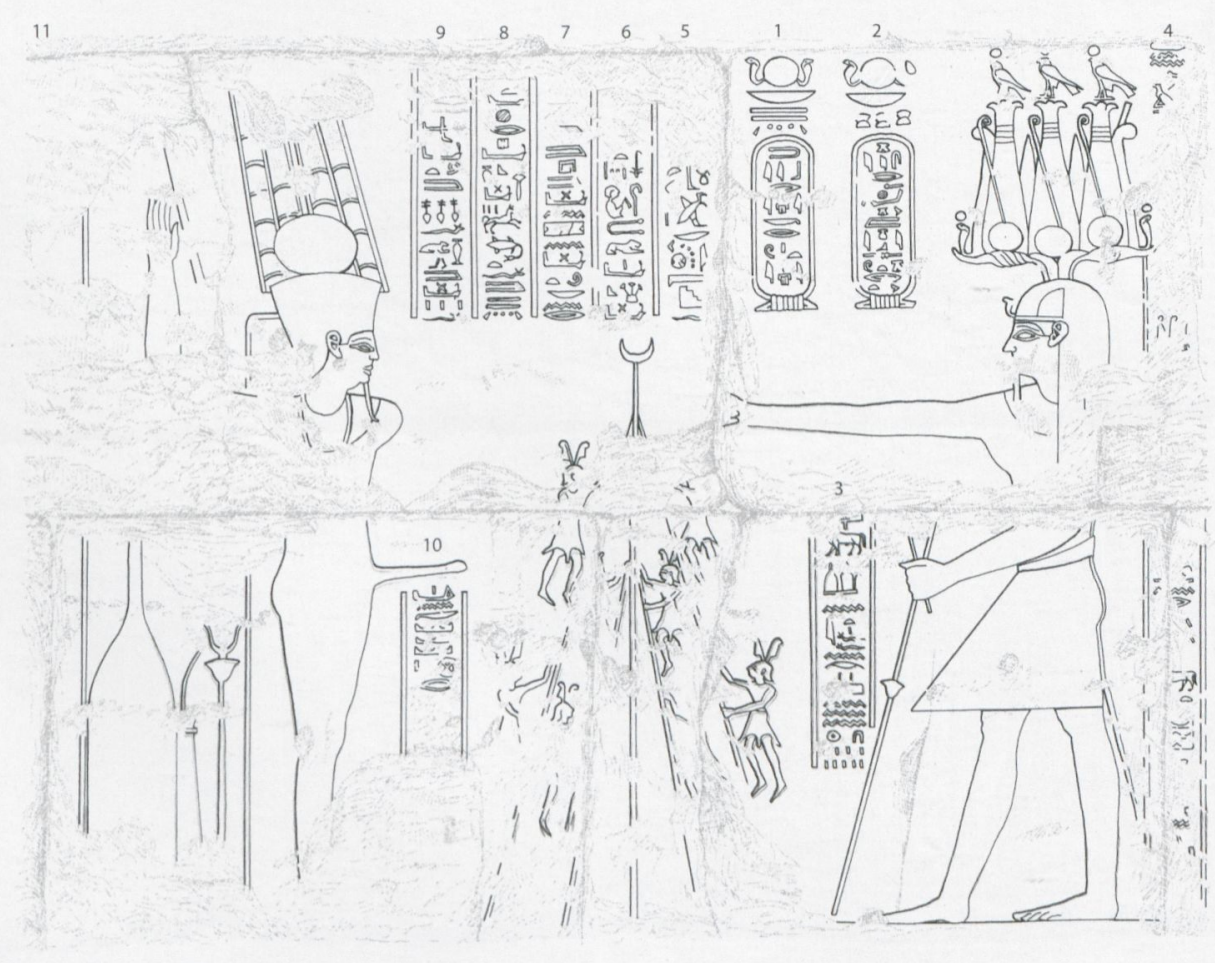

5. Drawing of Shanhūr scene 123, Western exterior wall (drawing by T. L. Sagrillo) (zu Minas-Nerpel und De Meyer, Raising the Pole for Min). 
TAFEL XXII
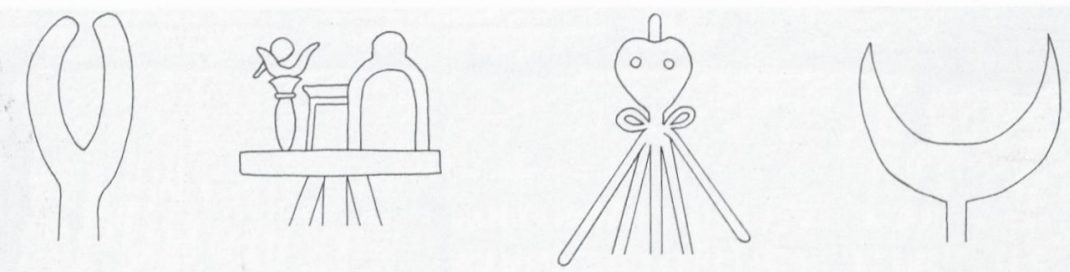

6. Drawing of pole tops: 1) app. 14; 2) app. 29; 3) app. 23; 4) app. 32 (drawings by M. De Meyer) (zu Minas-Nerpel und De Meyer, Raising the Pole for Min).
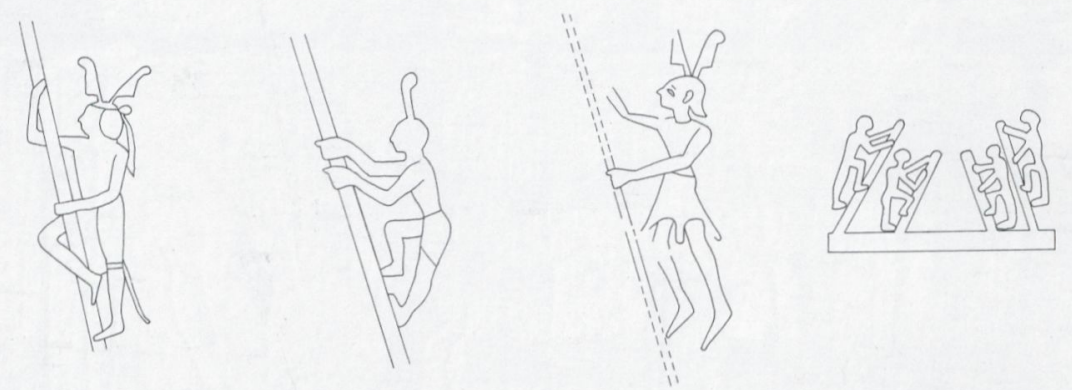

7. Drawing of pole-climbers: 1) app. 14; 2) app. 29; 3) app. 32; 4) Esna no. 208, 27 (73), see n. 37 (drawings by M. De Meyer) (zu Minas-Nerpel und De Meyer, Raising the Pole for Min).

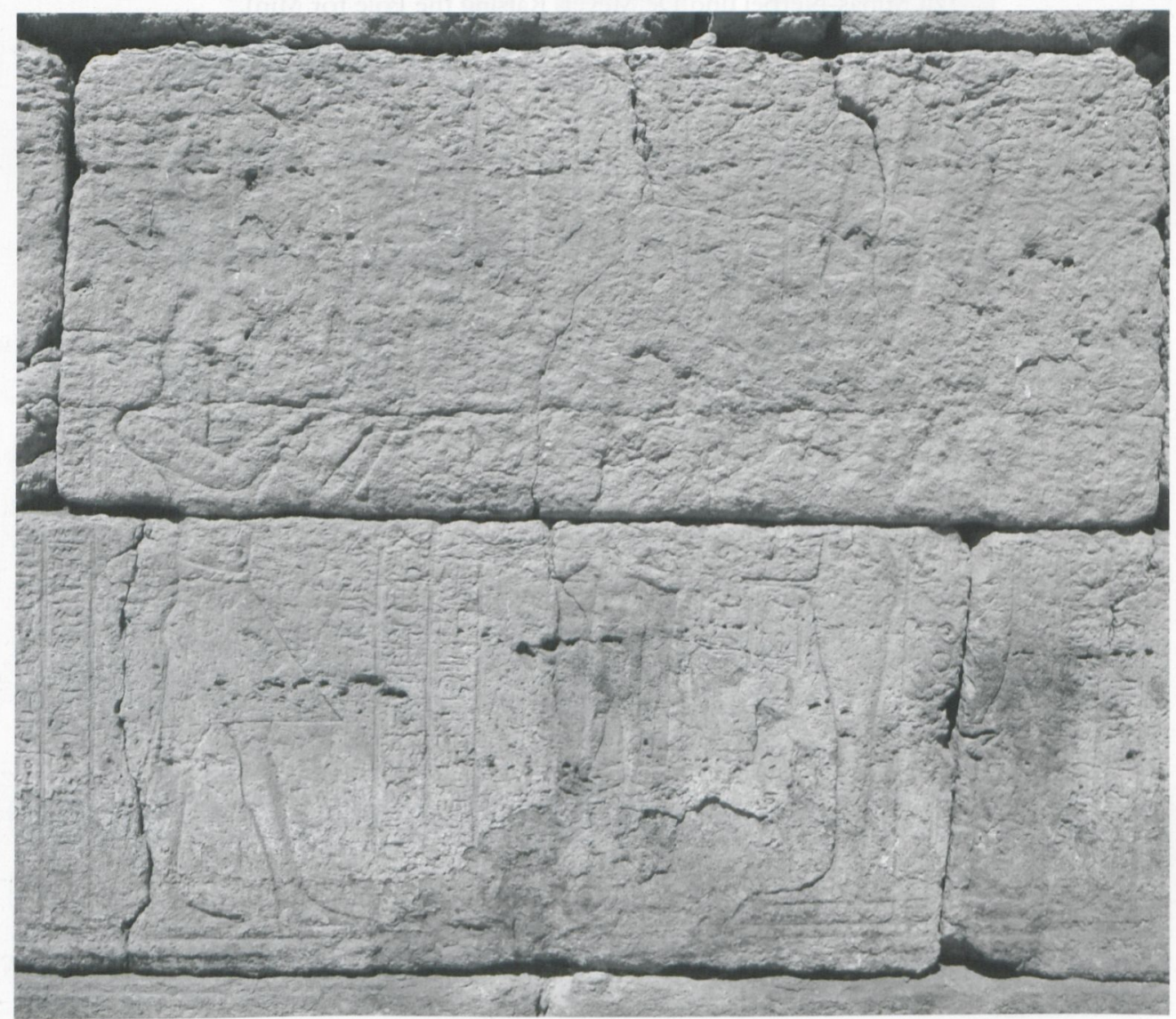

8. Photograph of Shanhūr scene 161 on the Eastern exterior wall (photograph by M. De Meyer) (zu Minas-Nerpel und De Meyer, Raising the Pole for Min). 


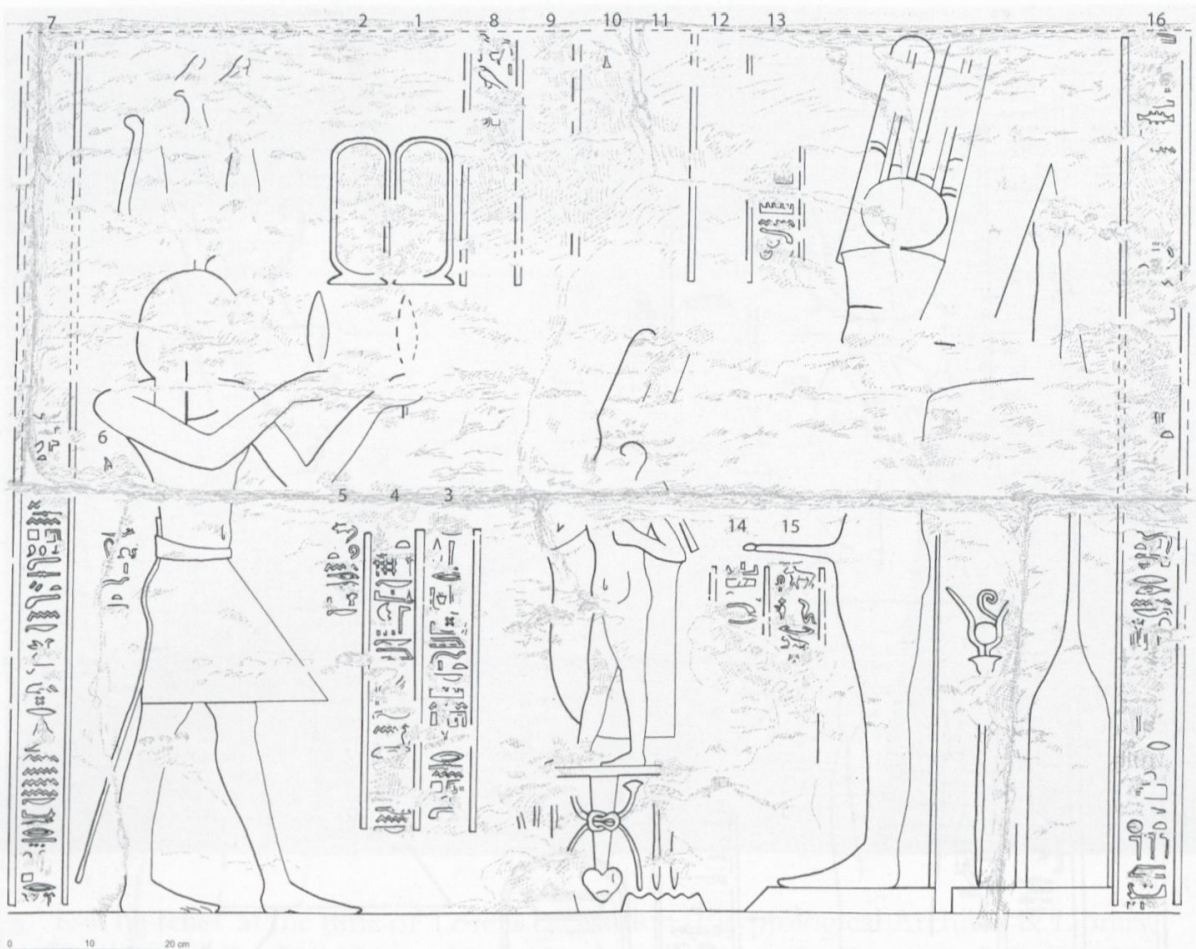

9. Drawing of Shanhūr scene 161, Eastern exterior wall (drawing by T. L. Sagrillo) (zu Minas-Nerpel und De Meyer, Raising the Pole for Min).

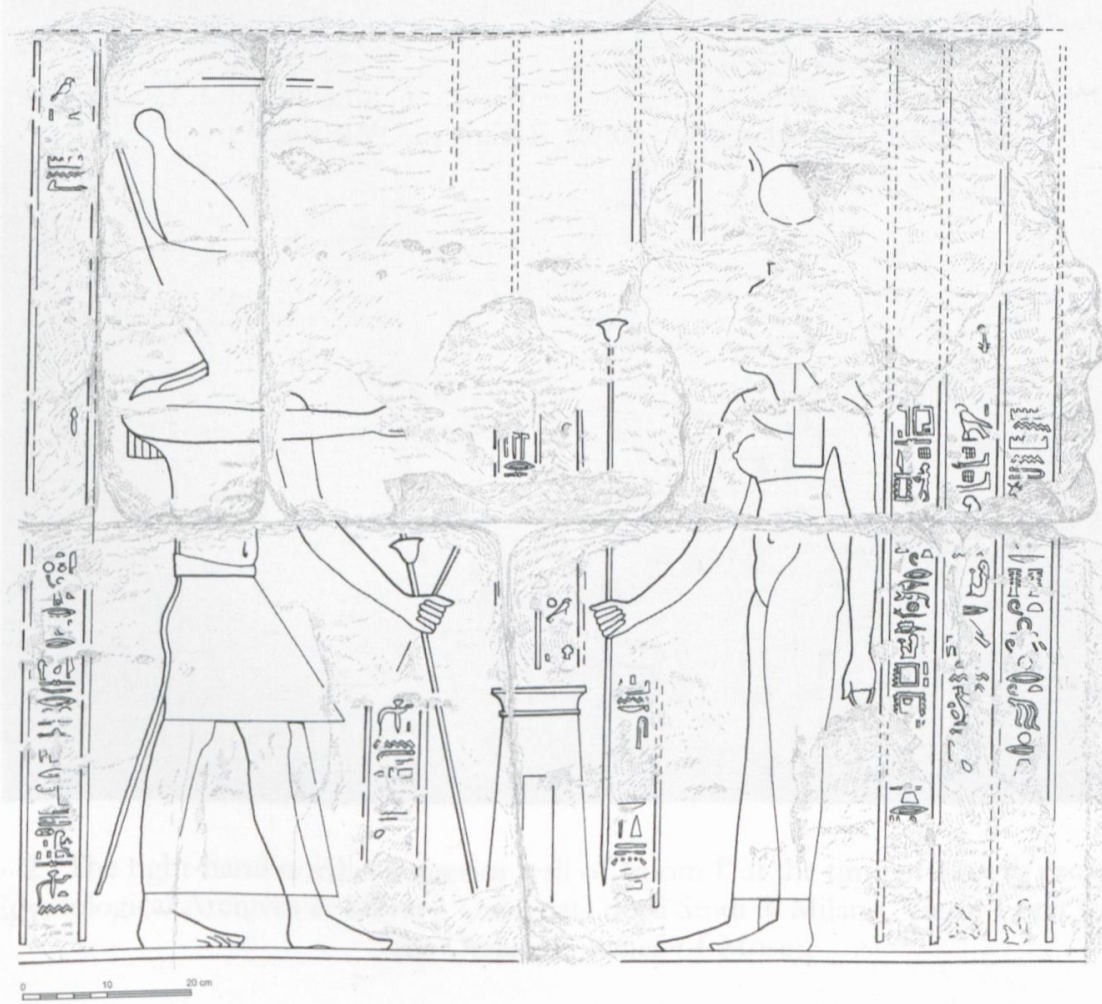

10. Drawing of Shanhūr scene 162, Eastern exterior wall (drawing by T. L. Sagrillo) (zu Minas-Nerpel und De Meyer, Raising the Pole for Min). 

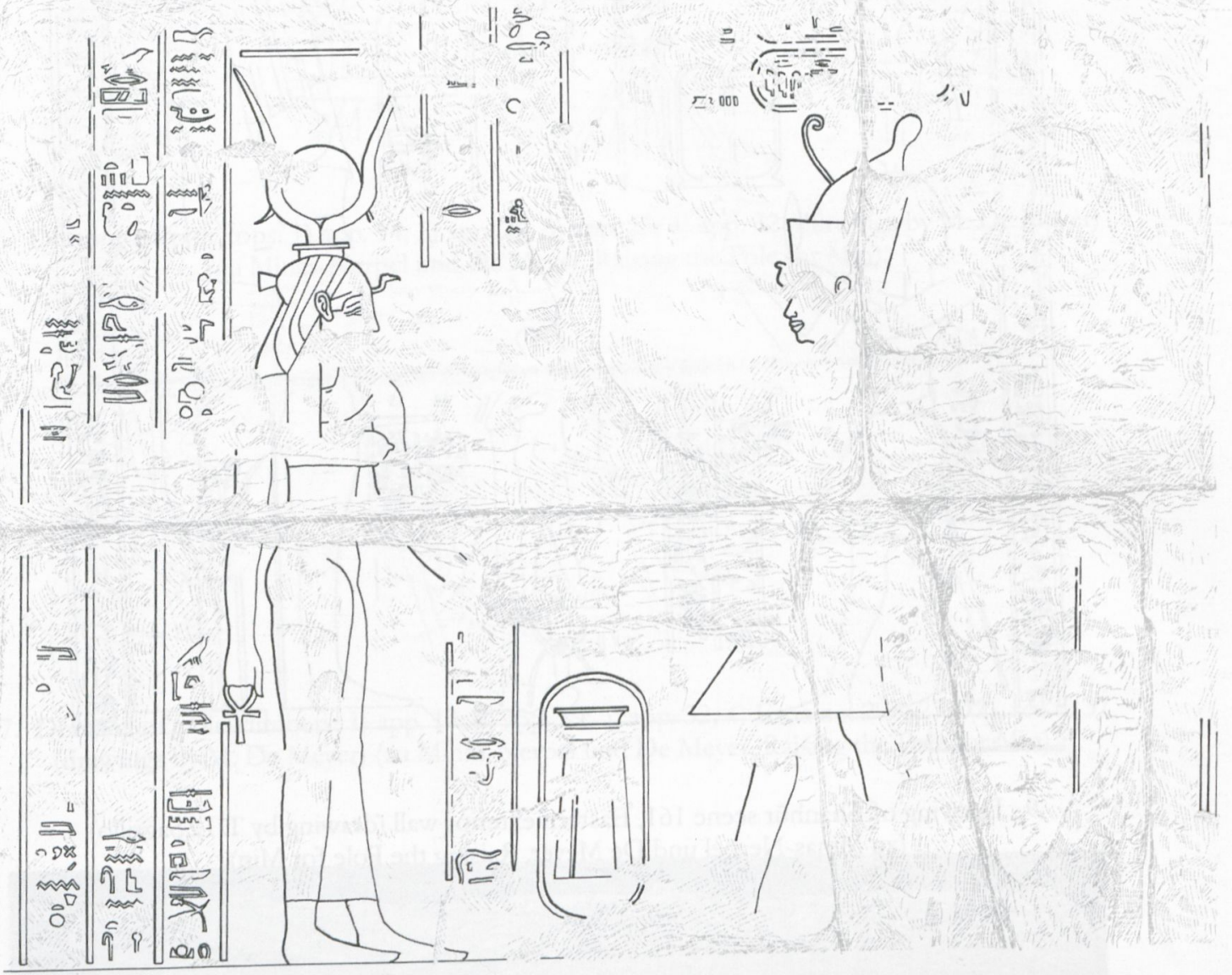

11. Drawing of Shanhūr scene 124, Western exterior wall (drawing by T. L. Sagrillo) (zu Minas-Nerpel und De Meyer, Raising the Pole for Min). 